\title{
17. COCCOLITH STRATIGRAPHY, LEG 10, DEEP SEA DRILLING PROJECT ${ }^{1}$
}

\author{
David Bukry, U.S. Geological Survey, La Jolla, California
}

\section{INTRODUCTION}

Leg 10 of the Deep Sea Drilling Project, February to April 1970, through the Gulf of Mexico from Galveston to Miami, recovered 162 cores at 13 drilling sites (Figure 1). Light-microscope techniques were used to study the coccoliths of 270 samples from these cores. The zonal assignment of the cores examined, given in Table 1, uses the coccolith zones described in the Leg 3 report (Bukry and Bramlette, 1970) and the Leg 7 report (Bukry, 1971a), with the addition of a new Paleocene subzone. An index of the species considered follows a summary of the coccolith stratigraphy. Coccolith species identified in specific samples are listed for each hole by time-stratigraphic series and biostratigraphic zone.

\section{SAMPLE DESIGNATION}

Sample numbers for each site consist of elements in the following sequence: cruise-leg number; drill-hole number; core number; core-section number; interval in centimeters below the top of each core-section plastic liner. For example, 10-94-5-1 $(63-64 \mathrm{~cm})$, indicates that the sample came from Leg 10, Hole 94, the fifth barrel of core recovered from that hole, the first section from the top of that core, and from 63 to $64 \mathrm{~cm}$ below the top of the section. Core sections are 1.5 meters long; most core runs were 9.1 meters long, but occasionally the core liners were not full. In this report, the tops of recoveries are arbitrarily placed at the top of the core runs, and an approximate depth in meters below the sea floor follows each sample number.

\section{SUMMARY OF COCCOLITH STRATIGRAPHY}

\section{Hole 85}

In Hole 85, Quaternary nannoplankton assemblages containing reworked Upper Cretaceous taxa characterize all samples studied, which lie between 27 and 212 meters below the sea floor. The coring site is just seaward of the Campeche Escarpment. The sediment samples are poorly sorted as to size, and the reworked Cretaceous taxa are common resistant forms such as Arkhangelskiella cymbiformis, Eiffellithus turriseiffeli, Micula decussata, Prediscosphaera cretacea, and Watznaueria barnesae. These forms typify nearshore Quaternary sediments in areas such as this and the Black Sea, where nearby Cretaceous deposits are eroded. The truly Quaternary assemblages are best represented in samples from Cores 4 and 5 .

'Publication authorized by the Director, U.S. Geological Survey.

\section{Hole 86}

Coccolith assemblages from the upper nine cores (14 to $551 \mathrm{~m}$ ) at Site 86 on the Campeche Escarpment are Holocene to upper Miocene, middle Oligocene, and Paleocene. The Holocene to upper Miocene assemblages are well preserved and diversified; the genus Scyphosphaera is especially well represented. The middle Oligocene assemblages are typically open ocean in aspect, but the upper and lower Paleocene coccolith assemblages show an abundance of Braarudosphaera and Micrantholithus, which are typical of shallow-water deposits. The middle Paleocene Heliolithus kleinpelli Zone is well developed throughout Core 8, but lacks Braarudosphaera and Micrantholithus. These shallow-water indicators are most abundant and attain their largest size in samples from the lower Paleocene Cruciplacolithus tenuis Zone of Core 9, where they are the dominant taxa of the assemblage.

\section{Hole 87}

Coccoliths are rare in the two samples examined from Hole 87. Middle or upper Miocene taxa are mixed with Eocene taxa. Among the taxa with limited ranges, the oldest is Discoaster saipanensis [middle and upper Eocene] and the youngest, Catinaster coalitus [lower upper Miocene]. The depth of the samples examined is about 649 meters below the sea floor. Similar samples were obtained by DSDP Leg 1 in the same area at Site 3 from cores at 611 meters and 620 meters. These samples also contain sparse upper Miocene coccoliths with reworked Eocene and Cretaceous taxa.

\section{Hole 88}

The five cores of coccolith ooze from Hole 88 range from Holocene at the surface to lower Pliocene or upper Miocene at the 131 meter depth. The Quaternary assemblages are especially rich and contain most of the taxa described by Boudreaux and Hay (1969) from the Nicaragua Rise. Emiliania annula is abundant in the lower Pleistocene of Core 2 and upper Pliocene of Core 3.

\section{Hole 89}

A Holocene to upper Miocene section of coccolith-rich sediment was discoritınuously cored from the surface to 376 meters. Quaternary and upper Pliocene samples contain reworked Cretaceous taxa, whereas upper Miocene samples contain Paleocene and Eocene reworked taxa in addition to Cretaceous forms. Coccoliths are common except in the upper Miocene Core 6, which contains abundant detrital material that dilutes the assemblage.

\section{Hole 90}

Hole 90 is located at the base of the continental rise, east of the Mexican coast. Whereas the upper four cores 


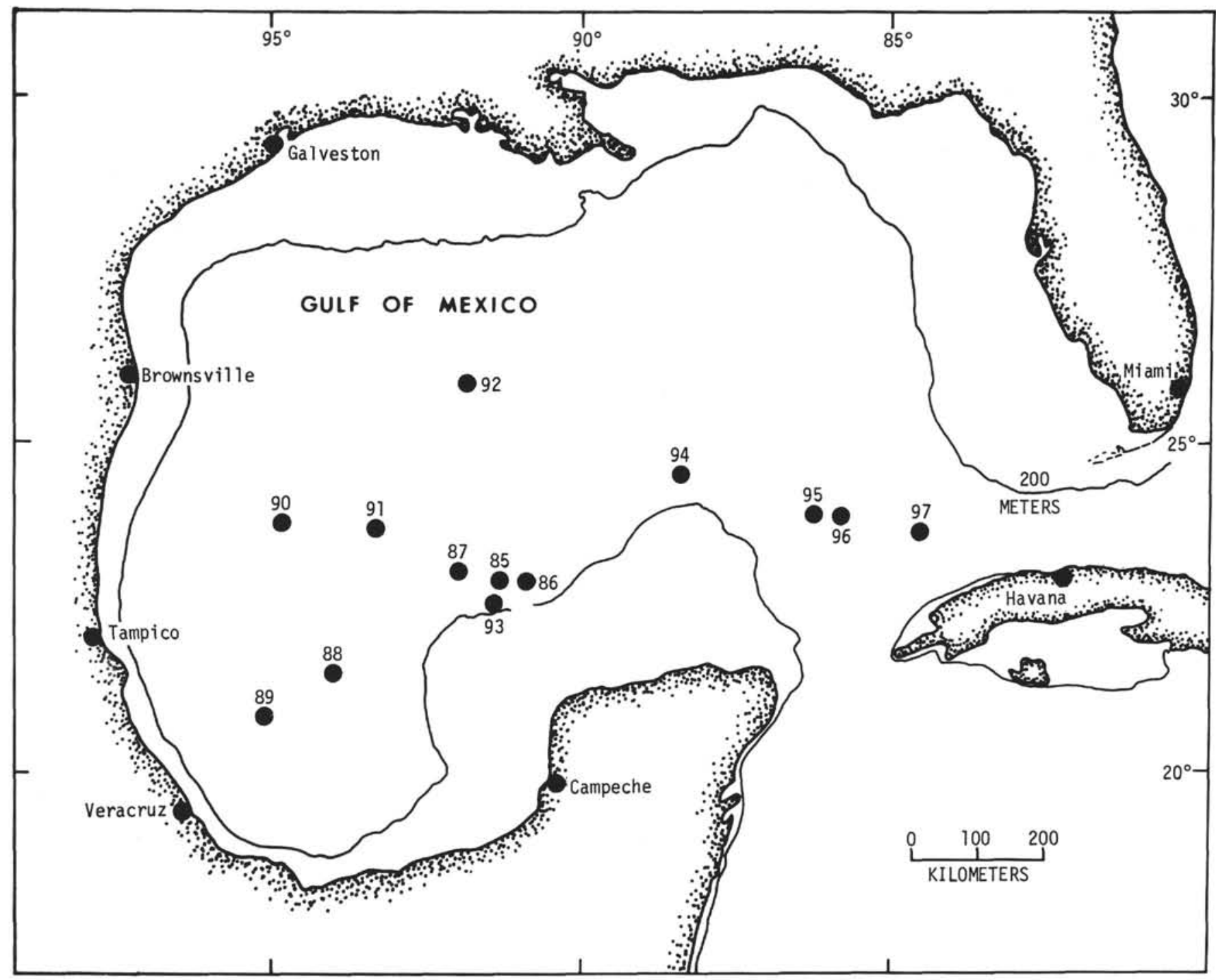

Figure 1. Sites cored during Leg 10, Deep Sea Drilling Project, in the Gulf of Mexico.

recovered nearly pure Holocene to upper Miocene coccolith ooze, the deeper nine cores recovered upper Miocene to middle Miocene sediment that is diluted by detrital material. Discoaster quinqueramus is generally common in the upper Miocene samples from Cores 5 to 7 , and this indicates a correlation to the Discoaster quinqueramus Zone. In deeper cores (9-13) from 472 to 764 meters, assemblages diluted by detritus are apparently mixed. The occurrence of Catinaster coalitus, C. mexicanus, Cyclococcolithina leptopora, Discoaster bollii, and D. braarudii in a sample from the base of Core 11 at 682 meters indicates the lower upper Miocene for that level. The oldest assemblages in Core 13 are considered middle middle Miocene on the basis of Cyclococcolithina leptopora, Discolithina multipora, Discoaster sp. cf. D. bollii, D. exilis, D. variabilis, Reticulofenestra pseudoumbilica, and Sphenolithus neoabies. All these taxa have their first common occurrence in the middle Miocene. In addition, the absence of the dominant species of the lower Miocene-Cyclococcolithina neogammation and Discoaster deflandrei (which also range into the lower middle Miocene) - provides further support for the middle middle Miocene assignment.
Hole 91

Hole 91 is located on the abyssal plain of the northern Gulf of Mexico at the base of the continental rise to the Texas Gulf Coast. Coccoliths are generally rare throughout the 25 cores, which range in age from Holocene or late Pleistocene at 61 meters, to late or middle Miocene at 896 meters. Whereas the upper Pliocene to upper upper Miocene coccolith assemblages are composed of normal compliments of diagnostic taxa in Cores 8 to 10 , the younger sediment in Cores 1 to 7 and the older sediment in Cores 11 to 25 are barren, containing only a few long-ranging taxa, or reworked Upper Cretaceous taxa.

\section{Hole 92}

Eleven cores were cut at this location on the Sigsbee Escarpment to determine if this physiographic feature is a result of salt intrusion. Samples from Cores 2 to 11 were examined. Cores 2 to 5 are Pleistocene with reworked Upper Cretaceous, and the detrital component greatly dilutes the Pleistocene coccoliths. Rare specimens of Coccolithus pelagicus, Helicopontosphaera kamptneri, and reworked Cretaceous taxa in Core 6 indicate an 
TABLE 1

Zonal and Geologic Age Assignments of Cores from Deep Sea Drilling Project Leg 10 as Indicated by Coccoliths in Examined Samples

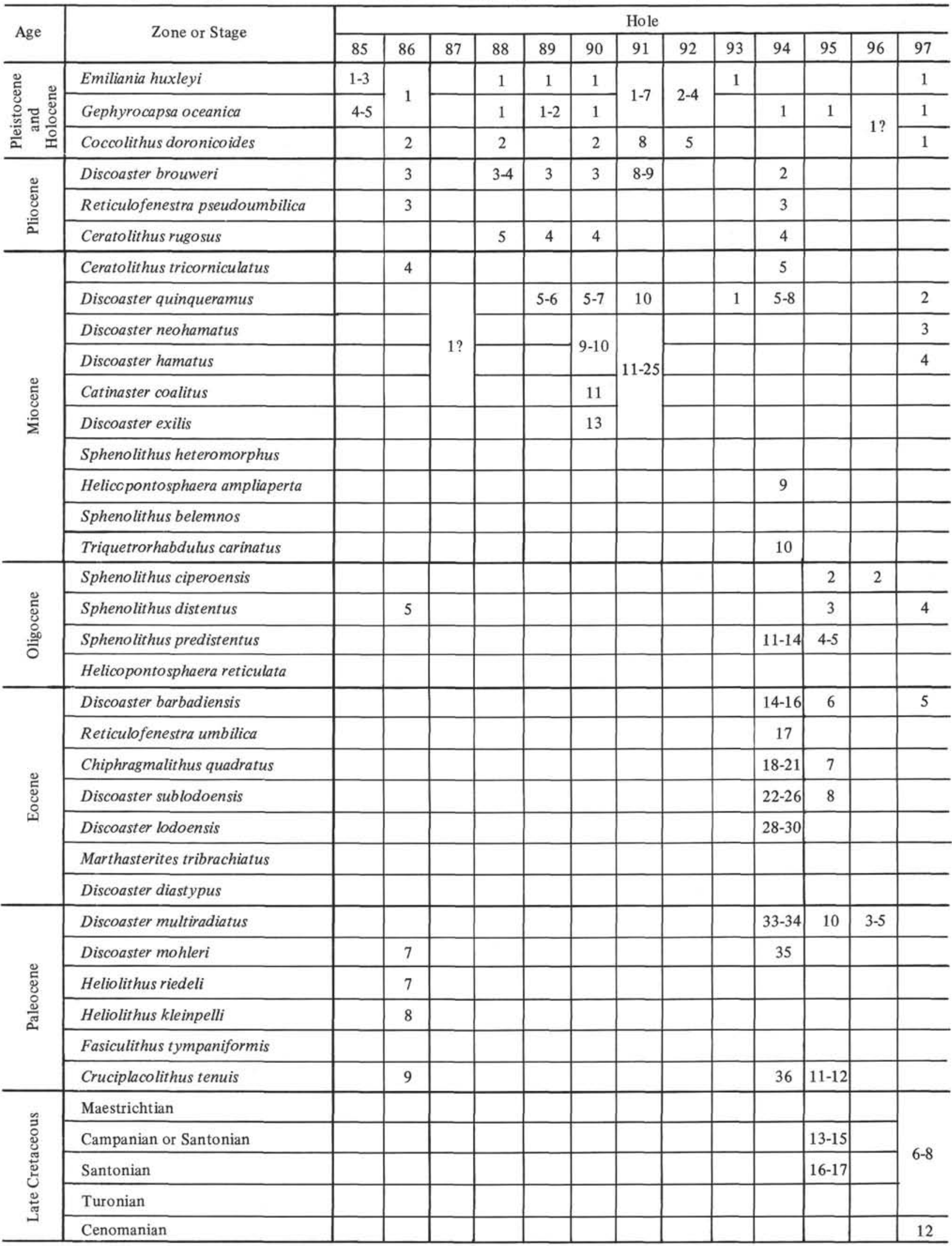


indeterminate late Cenozoic age. Samples from deeper cores are barren of coccoliths.

\section{Hole 93}

A single surface core was recovered from Hole 93 in a submarine canyon that incises Campeche Bank. The top core section was nearly empty, and the shallowest sample, designated 10-93-1-1 (128-129 $\mathrm{cm}$ ) (depth approximately $10 \mathrm{~cm}$ ), is a Holocene coccolith ooze containing a large form of Ceratolithus cristatus. The deepest sample (approximately $1 \mathrm{~m}), 10-93-1-2(65-67 \mathrm{~cm})$, contains an upper Miocene coccolith assemblage, (including Ceratolithus tricorniculatus, Discoaster quinqueramus, and Triquetrorhabdulus rugosus), that is considered to represent the Discoaster quinqueramus Zone.

\section{Hole 94}

Coring Site 94 is at the margin of Campeche Bank. Cores 1 to 10, ranging in age from late Pleistocene to earliest Miocene, were cut discontinuously between the surface and 339 meters. Cores 11 to 27 and 32 to 36 were cut continuously and recovered a middle Oligocene to lower Paleocene section, including an exceptionally thick middle Eocene. The only samples available from Cores 37 to 40 are barren.

The Pleistocene to upper Miocene coccolith ooze samples from Cores 1 to 5 contain a plexus of large Scyphosphaera species typifying warm, moderately shallow, oceanic deposits. This relation is demonstrated at the coring sites of equatorial Leg 7 where Scyphosphaera is more common in the shallow Sites 62 and 64 (respectively 2591 and $2052 \mathrm{~m}$ water depth) than at the deeper Site 63 (4472 $\mathrm{m})$. The upper Miocene Discoaster quinqueramus Zone assemblages of Cores 6 to 8 resemble those of the tropical Pacific Ocean because of their lack of Reticulofenestra pseudoumbilica and also because they have Discoaster berggrenii more abundant than $D$. quinqueramus in the lower part of the zone (Core 8).

Identification of the Helicopontosphaera ampliaperta Zone of the lower Miocene in deep-ocean sediment has been based on the recognition of an assemblage where Discoaster deflandrei is the overwhelmingly dominant discoaster; Cyclococcolithina neogammation dominates the cyclococcolithids; and Sphenolithus heteromorphus is common (Bukry, 1971a). In Core 9 the name-giving species of the Helicopontosphaera ampliaperta Zone is present for only the second time in Deep Sea Drilling Project cores. The wide geographic occurrence of this species includes Trinidad, California, Indonesia, and Italy (Bramlette and Wilcoxon, 1967). Its limited oceanic occurrence can be attributed to either an ecologic preference for lowered salinities of coastal, and therefore shallow, waters, or to a greater solution susceptibility than other species of Helicopontosphaera. Although this species was cosmopolitan, and the stratigraphic interval of its occurrence has been cored repeatedly by the Deep Sea Drilling Project, only in this core and in one from Leg 4 in the Caribbean has the taxon been reported.

The occurrence in Hole 94 of many taxa that do not occur in coeval deep-ocean coccolith ooze suggests that the deposition depth at Hole 94 rarely approached that of a normal ocean basin. For example, comparison with Eocene coccolith assemblages of equivalent age from Gulf Coastal Plain outcrops and from cores of Leg 3 in the deep South Atlantic shows that in diversity and preservation the assemblages from Leg 10 in the Gulf of Mexico are more similar to the outcrop assemblages, which presumably represent deposition at continental-shelf depths (Table 2 ). The taxonomic differences between these areas result from varying degrees of coccolith solution susceptibility and to ecologic controls. Neritic assemblages show the most diversity and best preservation. Progressively deeper offshore assemblages lose diversity and show more solution etching of specimens. Two important controls in ordering the sequence of coccolith depletion in more offshore areas are the increase in salinity seaward of coastal waters and the decrease in calcite saturation with depth. The following list of lower Tertiary coccolith genera is ranked from those least likely to occur in deep-ocean deposits to those most characteristic of such deposits: Transversopontis, Syracosphaera, Rhabdosphaera, Discolithina [perforate], Micrantholithus, Braarudosphaera, Lophodolithus, Scyphosphaera, Helicopontosphaera, Discolithina [imperforate], Sphenolithus, Chiasmolithus, Reticulofenestra, Dictyococcites, Cyclococcolithina, Coccolithus, and Discoaster

There are more specimens of Transversopontis, Rhabdosphaera, Discolithina, and Braarudosphaera in the middle and lower Eocene assemblages. Therefore, assuming a deposition-depth control for Eocene coccolith dissolution, the middle and lower Eocene assemblages of Hole 94 were deposited at shallower depths than those of the upper Eocene.

Several hiatuses exist in the lower part of Hole 94. Missing intervals include the lower Oligocene Helicopontosphaera reticulata Zone, upper part of the upper middle Eocene Reticulofenestra umbilica Zone, lower Eocene Marthasterites tribrachiatus Zone, lower Eocene Discoaster diastypus Zone, and all of the middle Paleocene. The common occurrence of Cyclococcolithina reticulata down to the base of the upper Eocene section indicates that the lower part of the upper Eocene Discoaster barbadiensis Zone also is missing. The middle Eocene is particularly well represented at this site. A range chart of key middle and upper Eocene species is included in Table 3.

Paleocene assemblages of Cores 33 to 36 are not very diverse. The common occurrence of Campylosphaera eodela in the Discoaster multiradiatus Zone of Core 33 is repeated in Hole 95 and also in Hole 96, where it is accompanied by Rhomboaster cuspis. The occurrence of Campylosphaera eodela and Rhomboaster cuspis in assemblages of the upper Discoaster multiradiatus Zone is recorded as the Campylosphaera eodela Subzone. This biostratigraphic unit also occurs in Trinidad, on the Blake Plateau in the Atlantic Ocean (JOIDES Core 4), and on the Shatsky Rise in the Pacific Ocean (DSDP Hole 47.2).

\section{Hole 95}

Hole 95, on the Campeche Escarpment, was drilled to determine how long this area had been accumulating pelagic sediment. Samples available from the upper 17 cores contain good coccolith assemblages representing 
TABLE 2

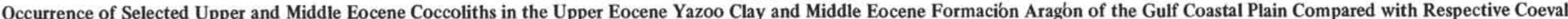
Occurrences in Hole 94 of DSDP Leg 10 and Holes 19 and $20 \mathrm{C}$ from the South Atlantic Ocean. The South Atlantic Samples are Believed to Represent a Residuum from Partial Calcite Solution Occurring at Great Depth of Deposition in Response to Aggressive Bottom Waters (see the "Mesolytic Dissolution Facies" of Hsü and Andrews, 1970)

\begin{tabular}{|c|c|c|c|c|c|c|c|c|c|c|c|c|c|c|c|c|c|c|c|c|c|c|c|c|c|c|c|c|c|c|c|c|c|}
\hline & \multicolumn{33}{|c|}{ Upper Eocene Coccoliths } \\
\hline & 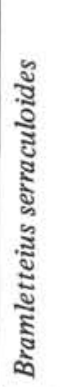 & 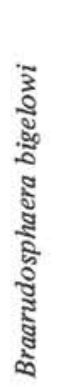 & 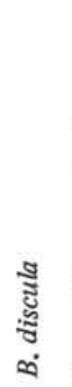 & 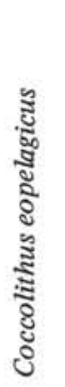 & 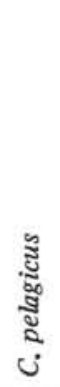 & 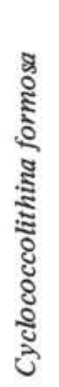 & 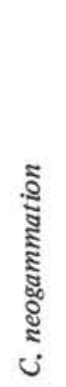 & 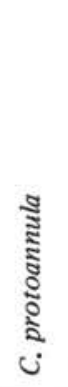 & 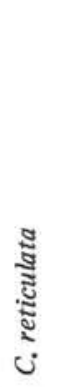 & 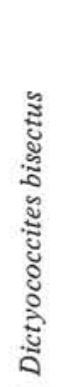 & 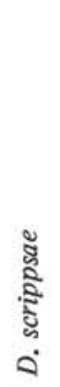 & 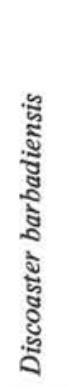 & $\begin{array}{l}\tilde{\Xi} \\
\tilde{\Xi} \\
\tilde{\Xi} \\
\text { ¿ี }\end{array}$ & 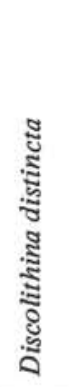 & 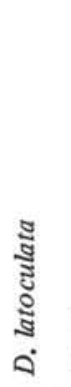 & 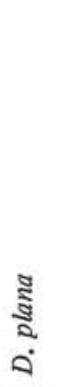 & 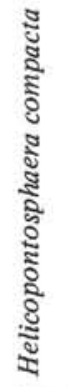 & 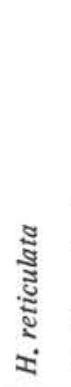 & 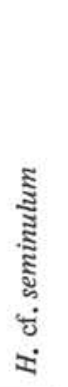 & 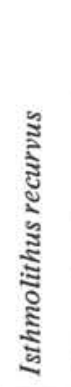 & 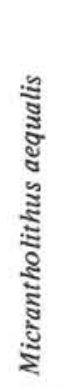 & 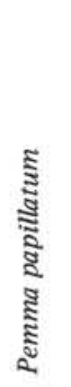 & 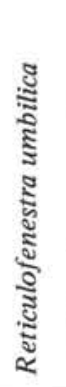 & 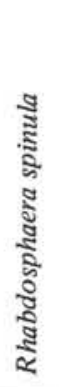 & 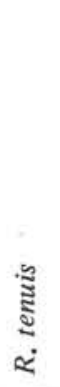 & 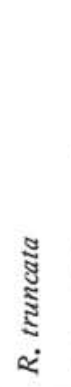 & 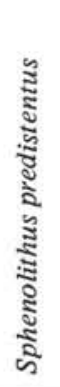 & 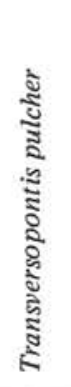 & $\begin{array}{l}\text { ปี } \\
\text { Nै } \\
\text { N. } \\
\stackrel{2}{*}\end{array}$ & 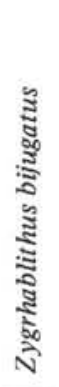 & & & \\
\hline $\begin{array}{l}\text { Gulf Coastal Plain } \\
\text { Yazoo Clay }\end{array}$ & $\mathrm{x}$ & $\mathrm{X}$ & $\mathrm{x}$ & $\mathrm{X}$ & $\mathrm{x}$ & $\mathrm{X}$ & $\mathrm{X}$ & $\mathrm{x}$ & $\mathrm{X}$ & $\mathrm{X}$ & $\mathrm{x}$ & $\mathrm{X}$ & $\mathrm{X}$ & $\mathbf{x}$ & $\mathrm{x}$ & $\mathrm{x}$ & $\mathrm{X}$ & $\mathrm{x}$ & $\mathrm{x}$ & $\mathrm{X}$ & $\mathrm{x}$ & $\mathrm{x}$ & $\mathrm{x}$ & $\mathrm{x}$ & $\mathrm{x}$ & $\mathrm{x}$ & $\mathrm{x}$ & $\mathrm{x}$ & $\mathrm{X}$ & $\mathrm{x}$ & & & \\
\hline $\begin{array}{l}\text { Gulf of Mexico } \\
10-94-14-1(122-123 \mathrm{~cm})\end{array}$ & $\mathrm{x}$ & $\mathrm{x}$ & $\mathrm{x}$ & $\mathrm{X}$ & $\mathrm{X}$ & $\mathrm{X}$ & $\mathrm{x}$ & $\mathrm{X}$ & $\mathrm{X}$ & $\mathrm{x}$ & $\mathrm{X}$ & $\mathrm{X}$ & $\mathrm{X}$ & & & & $\mathrm{X}$ & $\mathrm{x}$ & & $\mathrm{X}$ & & $\mathrm{X}$ & $\mathrm{X}$ & & & & $\mathrm{X}$ & & & $\mathrm{X}$ & & & \\
\hline \multirow[t]{3}{*}{$\begin{array}{l}\text { South Atlantic Ocean } \\
3-19-5-4(79-80 \mathrm{~cm})\end{array}$} & $\mathrm{X}$ & & & $\mathrm{X}$ & $\mathrm{X}$ & $\mathrm{X}$ & & & & $\mathrm{X}$ & $\mathrm{x}$ & $\mathrm{X}$ & $\mathrm{x}$ & & & & & & & $\mathrm{X}$ & & & $\mathrm{x}$ & & & & & & & & & & \\
\hline & \multicolumn{33}{|c|}{ Middle Eocene Coccoliths } \\
\hline & 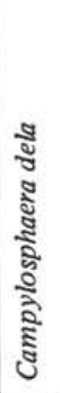 & 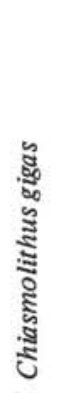 & 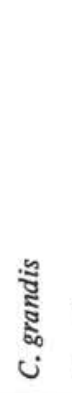 & 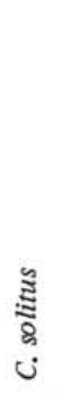 & 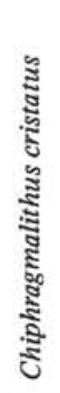 & 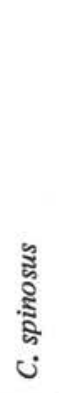 & 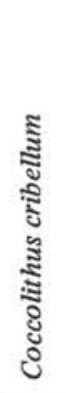 & 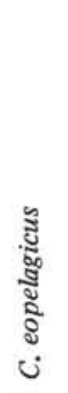 & 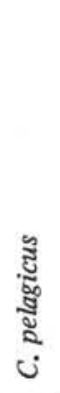 & 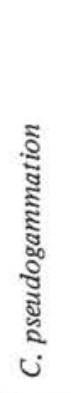 & 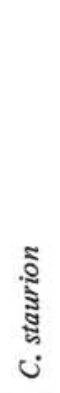 & 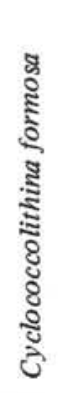 & 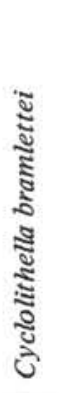 & 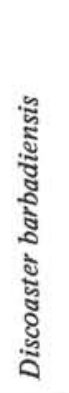 & 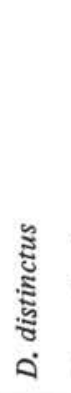 & 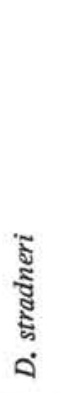 & 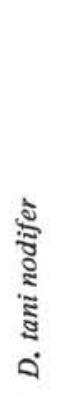 & 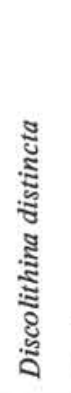 & 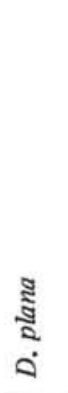 & 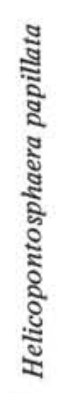 & 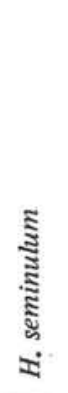 & 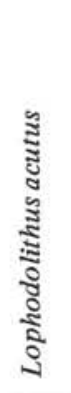 & 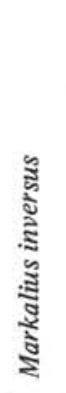 & 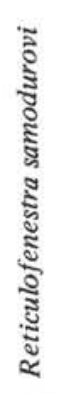 & 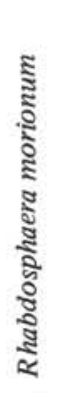 & 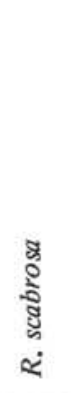 & $\begin{array}{l}\cong \\
\text { ป̃ } \\
\dot{\Sigma}\end{array}$ & 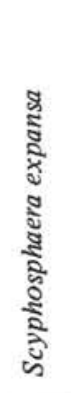 & 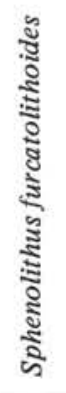 & 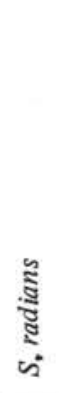 & 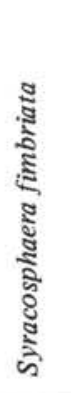 & 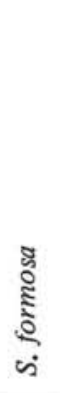 & 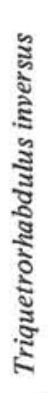 \\
\hline $\begin{array}{l}\text { Gulf Coastal Plain } \\
\text { Formacion Aragón }\end{array}$ & $\mathrm{X}$ & $\mathrm{x}$ & $\mathrm{X}$ & $\mathrm{X}$ & $\mathrm{x}$ & $\mathrm{X}$ & $\mathrm{x}$ & $\mathrm{X}$ & $\mathrm{x}$ & $\mathrm{x}$ & $\mathrm{X}$ & $\mathrm{x}$ & $\mathrm{x}$ & $\mathrm{x}$ & $\mathrm{x}$ & $\mathrm{x}$ & $\mathrm{x}$ & $\mathrm{x}$ & $\mathrm{x}$ & $\mathrm{X}$ & $\mathrm{X}$ & $\mathrm{X}$ & $\mathrm{X}$ & $\mathrm{X}$ & $\mathrm{X}$ & $x$ & $\mathrm{X}$ & $\mathrm{X}$ & $X$ & $\mathrm{X}$ & $\mathrm{X}$ & $\mathrm{X}$ & $\mathrm{X}$ \\
\hline $\begin{array}{l}\text { Gulf of Mexico } \\
10-94-20-3(67-68 \mathrm{~cm})\end{array}$ & $\mathrm{X}$ & $X$ & $\mathrm{X}$ & $\mathrm{X}$ & $\mathrm{X}$ & & & $\mathrm{X}$ & $\mathrm{X}$ & & & $\mathrm{X}$ & $\mathrm{X}$ & $\mathrm{X}$ & $x$ & $\mathrm{X}$ & $x$ & $\mathrm{X}$ & $\mathrm{X}$ & & $\mathrm{X}$ & & $\mathrm{X}$ & $\mathrm{X}$ & & & & & $\mathrm{X}$ & $\mathrm{X}$ & & & $\mathrm{X}$ \\
\hline $\begin{array}{l}\text { South Atlantic Ocean } \\
3-20 C-5 C-1(148-150 \mathrm{~cm})\end{array}$ & $\mathrm{x}$ & & $\mathrm{X}$ & & $\mathrm{X}$ & & & $\mathrm{X}$ & $\mathrm{X}$ & & & $\mathrm{X}$ & $X$ & $\mathrm{X}$ & & & & & & & & & & $X$ & & & & & & $\mathrm{X}$ & & & $\mathrm{X}$ \\
\hline
\end{tabular}


TABLE 3

Occurrence of Key Coccoliths in Middle and Upper Eocene Samples from Leg 10, Hole 94. A Sedimentary Discontinuity That Cuts Out the Lower Discoaster barbadiensis Zone and Practically All of the Reticulofenestra umbilica Zone Accounts for the Great Floral Change Between Samples 10-94-16-3 $(63-64 \mathrm{~cm})$ and 10-94-17-1 $(17-18 \mathrm{~cm})$

\begin{tabular}{|c|c|c|c|c|c|c|c|c|c|c|c|c|c|c|c|c|c|c|c|c|c|c|c|c|c|c|c|c|c|c|c|}
\hline & & \multicolumn{30}{|c|}{ Middle and Upper Eocene Coccoliths } \\
\hline Zones & 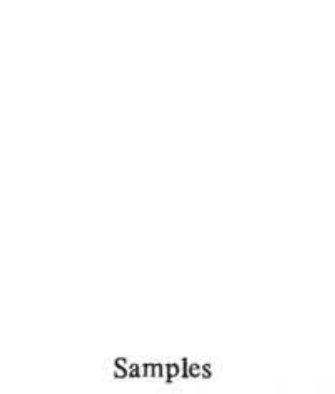 & 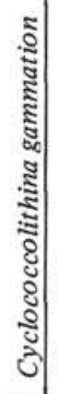 & 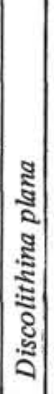 & 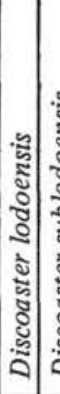 & & 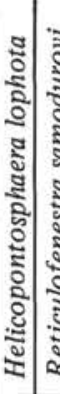 & 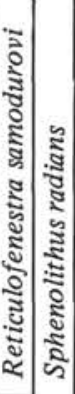 & 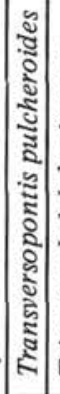 & 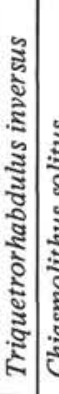 & 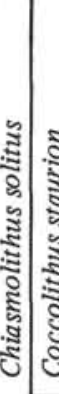 & 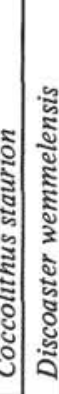 & 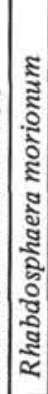 & 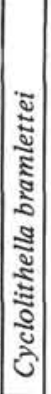 & 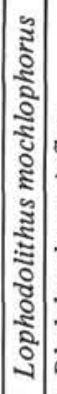 & 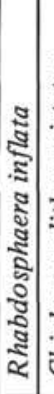 & 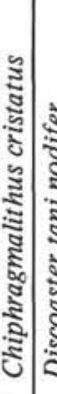 & 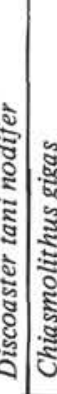 & 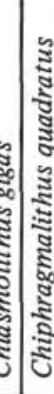 & 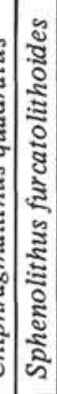 & 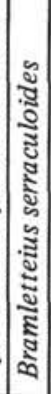 & 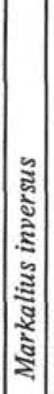 & 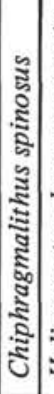 & 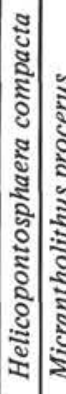 & 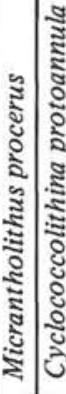 & 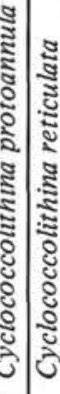 & 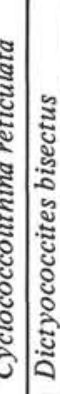 & 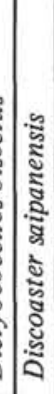 & 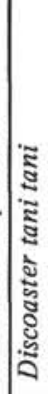 & 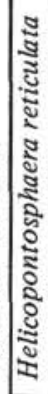 & 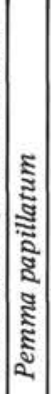 & 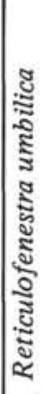 \\
\hline $\begin{array}{c}\text { Discoaster barbadiensis } \\
\text { Zone }\end{array}$ & $\begin{array}{l}10-94-14-1(122-123 \mathrm{~cm}) \\
10-94-16-3(63-64 \mathrm{~cm})\end{array}$ & & & & & & & & & & & & & & & & $\begin{array}{l}\mathrm{X} \\
\mathrm{X}\end{array}$ & & & $\begin{array}{l}\mathrm{X} \\
\mathrm{X}\end{array}$ & $\mathrm{x}$ & & $\begin{array}{l}\mathrm{x} \\
\mathrm{x}\end{array}$ & $\begin{array}{l}\mathrm{X} \\
\mathrm{X}\end{array}$ & \begin{tabular}{l|l}
$X$ & $X$ \\
$X$ & $X$
\end{tabular} & \begin{tabular}{l|l}
$X$ & $X$ \\
$X$ & $X$
\end{tabular} & $\mathrm{x}$ & $\mathrm{X}$ & $\mathrm{X}$ & $\begin{array}{l}\mathrm{x} \\
\mathrm{x}\end{array} \mid$ & $\begin{array}{l}\mathrm{X} \\
\mathrm{X}\end{array}$ \\
\hline $\begin{array}{c}\text { Lower Reticulofenestra } \\
\text { umbilica Zone }\end{array}$ & $\begin{array}{l}10-94-17-1(17-18 \mathrm{~cm}) \\
10-94-17-3(63-64 \mathrm{~cm})\end{array}$ & & & & & & $\begin{array}{l}\mathrm{X} \\
\mathrm{X}\end{array}$ & & \begin{tabular}{l|l}
$\mathrm{x}$ & $\mathrm{X}$ \\
$\mathrm{X}$ & $\mathrm{X}$
\end{tabular} & \begin{tabular}{l|l}
$\mathrm{X}$ & $\mathrm{X}$ \\
$\mathrm{X}$ & $\mathrm{X}$
\end{tabular} & $\begin{array}{l}x \\
X\end{array}$ & & $\mathrm{x}$ & & & & $\mathrm{x}$ & & $\begin{array}{l}\mathrm{X} \\
\mathrm{X}\end{array}$ & $\mathrm{x}$ & & & \begin{tabular}{l|l}
$\mathrm{x}$ & $\mathrm{x}$ \\
$\mathrm{x}$ & $\mathrm{x}$
\end{tabular} & \begin{tabular}{l|l}
$\mathrm{X}$ & \\
$\mathrm{X}$ &
\end{tabular} & & & & & & & \\
\hline $\begin{array}{c}\text { Chiphragmalithus quadratus } \\
\text { Zone }\end{array}$ & $\begin{array}{l}10-94-18-1(63-64 \mathrm{~cm}) \\
10-94-18-4(63-64 \mathrm{~cm}) \\
10-94-19-2(65-66 \mathrm{~cm}) \\
10-94-19-5(63-64 \mathrm{~cm}) \\
10-94-20-2(62-63 \mathrm{~cm}) \\
10-94-20-4(63-64 \mathrm{~cm}) \\
10-94-21-2(0-2 \mathrm{~cm})\end{array}$ & & & $\mathrm{X}$ & & \begin{tabular}{l|l} 
& $x$ \\
$x$ & $x$ \\
$x$ & $x$ \\
$x$ \\
$X$ \\
$x$ \\
$x$
\end{tabular} & \begin{tabular}{l|l|}
$\mathrm{X}$ & \\
$\mathrm{X}$ & \\
$\mathrm{X}$ & \\
$\mathrm{X}$ & $\mathrm{x}$ \\
$\mathrm{X}$ & \\
$\mathrm{X}$ & \\
$\mathrm{X}$ & $\mathrm{x}$ \\
\end{tabular} & & 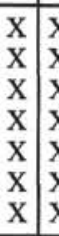 & \begin{tabular}{l|l}
$x$ & $x$ \\
$X$ & $X$ \\
$X$ & $X$ \\
$X$ & $X$ \\
$X$ & \\
$X$ & \\
$X$ &
\end{tabular} & \begin{tabular}{l|l}
$\mathrm{X}$ & \\
$\mathrm{X}$ & \\
$\mathrm{X}$ & $\mathrm{X}$ \\
$\mathrm{X}$ & $\mathrm{X}$
\end{tabular} & & $\begin{array}{l}\mathrm{X} \\
\mathrm{X} \\
\mathrm{X} \\
\mathrm{X} \\
\mathrm{X}\end{array}$ & & & $\mathrm{x}$ & \begin{tabular}{l|l}
$\mathrm{x}$ & \\
$\mathrm{x}$ & \\
$\mathrm{x}$ & $\mathrm{X}$ \\
$\mathrm{x}$ & $\mathrm{X}$ \\
& $\mathrm{y}$ \\
$\mathrm{x}$ & $\mathrm{y}$
\end{tabular} & \begin{tabular}{l|l}
$\mathrm{X}$ & \\
$\mathrm{X}$ & \\
$\mathrm{X}$ & \\
$\mathrm{X}$ & $\mathrm{X}$ \\
\end{tabular} & \begin{tabular}{l|l}
$\mathrm{X}$ \\
$\mathrm{X}$ \\
$\mathrm{X}$
\end{tabular} & $\begin{array}{l}\mathrm{x} \\
\mathrm{x} \\
\mathrm{x} \\
\mathrm{x}\end{array}$ & 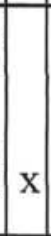 & \begin{tabular}{|l|}
$\mathrm{X}$ \\
$\mathrm{x}$
\end{tabular} & \begin{tabular}{|l|l}
$x$ & $x$ \\
$X$ & \\
\end{tabular} & $\mathrm{x}$ & & & & & & & \\
\hline $\begin{array}{c}\text { Discoaster sublodoensis } \\
\text { Zone }\end{array}$ & $\begin{array}{l}10-94-22-3(63-64 \mathrm{~cm}) \\
10-94-23-1(93-94 \mathrm{~cm}) \\
10-94-24-1(118-119 \mathrm{~cm}) \\
10-94-25-2(63-64 \mathrm{~cm}) \\
10-94-26-2(63-64 \mathrm{~cm}) \\
10-94-26-4(63-64 \mathrm{~cm}) \\
10-94-28-2(63-64 \mathrm{~cm}) \\
10-94-28-4(63-64 \mathrm{~cm})\end{array}$ & $\begin{array}{l}\mathrm{X} \\
\mathrm{X} \\
\mathrm{X}\end{array}$ & \begin{tabular}{|l|} 
\\
$\mathrm{x}$ \\
$\mathrm{x}$ \\
$\mathrm{x}$ \\
$\mathrm{x}$ \\
$\mathrm{x}$ \\
$\mathrm{x}$
\end{tabular} & \begin{tabular}{|l|l}
$\mathrm{x}$ & $y$ \\
$\mathrm{x}$ & $y$ \\
& $y$ \\
$\mathrm{x}$ & $y$ \\
$\mathrm{x}$ & $y$ \\
$\mathrm{x}$ & $y$ \\
$y$
\end{tabular} & 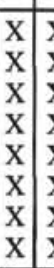 & \begin{tabular}{l|l}
$\mathrm{X}$ & $\mathrm{X}$ \\
$\mathrm{X}$ & $\mathrm{X}$ \\
$\mathrm{X}$ & $\mathrm{X}$ \\
$\mathrm{X}$ & $\mathrm{X}$ \\
$\mathrm{X}$ & $\mathrm{X}$ \\
$\mathrm{X}$ & $\mathrm{X}$ \\
$\mathrm{X}$ & $\mathrm{X}$ \\
$\mathrm{X}$ & $\mathrm{X}$
\end{tabular} & \begin{tabular}{l|l|}
$x$ & $x$ \\
$x$ & $x$ \\
$x$ & $x$ \\
$X$ & \\
$x$ & $x$ \\
$x$ & $x$ \\
$X$ & $x$ \\
$x$ & $x$
\end{tabular} & $\mathrm{x}$ & 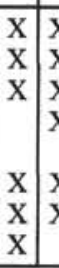 & \begin{tabular}{l|l}
$\mathrm{X}$ & \\
$\mathrm{X}$ & $\mathrm{X}$ \\
$\mathrm{X}$ & $\mathrm{X}$ \\
$\mathrm{X}$ & $\mathrm{X}$ \\
$\mathrm{X}$ & $\mathrm{X}$ \\
$\mathrm{X}$ & $\mathrm{X}$
\end{tabular} & \begin{tabular}{l|l}
$\mathrm{X}$ & \\
$\mathrm{X}$ & $\mathrm{X}$ \\
$\mathrm{X}$ & $\mathrm{X}$ \\
$\mathrm{X}$ & $\mathrm{X}$ \\
$\mathrm{X}$ & $\mathrm{X}$
\end{tabular} & $\mathrm{x}$ & $\begin{array}{l}\mathrm{x} \\
\mathrm{x} \\
\mathrm{x}\end{array}$ & \begin{tabular}{|l|} 
\\
$\mathrm{X}$ \\
$\mathrm{X}$ \\
$\mathrm{X}$ \\
$\mathrm{X}$
\end{tabular} & $\begin{array}{l}\mathrm{x} \\
\mathrm{x} \\
\mathrm{x} \\
\mathrm{x}\end{array}$ & $\mathrm{x}$ & $\mathrm{x}$ & & & & & & & & & & & & & & \\
\hline
\end{tabular}


moderately shallow pelagic Pleistocene to Upper Cretaceous (Santonian) deposits. The occurrence of species of Braarudosphaera, Micrantholithus, Permma, Rhabdosphaera, and the fossil holococcoliths Lanternithus and Peritrachelina, which typically are absent from coeval pelagic deposits from oceanic depths (Gartner and Bukry, 1969; Bukry, 1970; Bukry and others, 1971), provides an indication of the shallow-pelagic nature of the deposits. The section at Site 95 was cored discontinuously.

Core 1, cut at the surface, is in the Pleistocene Gephyrocapsa oceanica Zone, with reworked Miocene or Pliocene. Samples from 90 to 203 meters in Cores 2 to 5 contain upper and middle Oligocene assemblages. The lower Oligocene was bypassed in coring; a sample from the upper part of Core 6 contains an upper Eocene Discoaster barbadiensis Zone assemblage, including Cyclococcolithina reticulata which indicates the upper part of this zone. Lower cores sampled rich assemblages of middle Eocene coccoliths and contained a few species of Discolithina, Helicopontosphaera, and Rhabdosphaera which signify moderately shallow pelagic deposits. A short interval recovered in Cores 10 to 12 (364 m to $391 \mathrm{~m}$ deep), contains upper Paleocene and lower Paleocene assemblages. The lower Paleocene Cruciplacolithus tenuis Zone is dominated by Braarudosphaera spp., a characteristic of most shallow-water coccolith assemblages. Modern Braarudosphaera is most abundant in coastal areas of lower than normal salinity such as the Gulf of Maine (Gran and Braarud, 1935) and the Gulf of Panama (Smayada, 1966).

The Upper Cretaceous samples from Cores 13 to 17 contain assemblages comparable to the Taylor Marl and Austin Chalk of Texas and are part of the SantonianCampanian succession. Broinsonia parca occurs in Core 13 and Marthasterites sp. cf. M. furcatus in Core 17.

\section{Hole 96}

Hole 96 was drilled on a knoll in the Catoche Tongue area west of the Florida Straits to determine whether knolls in the eastern Gulf of Mexico have resulted from igneous or salt intrusion. Mechanical difficulties prevented completion of the objective. Of five cores taken, the lower three recovered upper Paleocene Discoaster multiradiatus Zone assemblages, Core 2 is upper Oligocene Sphenolithus ciperoensis Zone, and samples from Core 1 at 102, 105, and 108 meters are considered Pleistocene. Core 1 coccoliths are almost entirely reworked Upper Cretaceous. The diverse reworked assemblage probably represents erosion from lower Campanian strata. The Paleocene of Cores 3 to 5 is represented by a nonreworked assemblage. The presence of Campylosphaera eodela and Rhomboaster cuspis in this assemblage indicates the upper Discoaster multiradiatus Zone (the Campylosphaera eodela Subzone).

\section{Hole 97}

Coccolith assemblages from this site at the western approach to Florida Straits range in age from Holocene at the surface to early Cenomanian at 333 meters. Coring was discontinuous. The Cenozoic samples contain abundant coccoliths, but the Upper Cretaceous samples contain only rare coccoliths in a matrix of calcareous silt.
Core 1 has a condensed Quaternary section containing the characteristic Gulf or Caribbean assemblage illustrated by Boudreaux and Hay (1969). As at other sites in the Gulf of Mexico (Holes 89, 90, and 93), the Ceratolithus cristatus specimens in near-surface samples of probable Holocene age are distinctly larger than specimens from the underlying Pleistocene beds. Samples at 106 and 110 meters from Core 2 contain assemblages with Discoaster berggrenii, D. quinqueramus, D. surculus, Sphenolithus abies, and Triquetrorhabdulus rugosus, indicating the upper Miocene Discoaster quinqueramus Zone. Coccolithus pelagicus is abundant in these samples, but Reticulofenestra pseudoumbilica is missing. This same relation exists in Discoaster quinqueramus Zone samples from the tropical Pacific Ocean (Bukry, 1971ab) and represents a significant disjunction in the occurrence of $R$. pseudoumbilica. If the temperature-tolerance range for living C. pelagicus $\left(6^{\circ} \mathrm{C}\right.$ minimum, $15^{\circ} \mathrm{C}$ maximum; McIntyre and Bé, 1967) can be extrapolated to the late Miocene, then a period of cooling in the tropics is indicated. $R$. pseudoumbilica is common in younger sediment in the tropics until the middle Pliocene where it becomes extinct.

Upper Miocene Discoaster neohamatus Zone samples from Core 3 contain a spectacular diversity of Discoaster species, many of which represent mixing from slightly older late Miocene or middle Miocene strata.

Samples from the lower part of Core 4, described as a burrowed uniform soft chalk, contain middle Oligocene Sphenolithus distentus Zone assemblages including specimens of Braarudosphaera bigelowi, Helicopontosphaera spp., and Peritrachelina joidesa. These assemblages typically indicate moderately shallow deposition. The uppermost sample from the core contains an apparently mechanically brecciated mixture of middle Miocene taxa and taxa from the lower upper Miocene Discoaster hamatus Zone. As this core is stratigraphically about 60 meters deeper than Core 3 , which has a similar, though slightly younger, upper Miocene assemblage, no distinct hiatus can be demonstrated. Rather, the mechanically brecciated nature of this young sediment at the top of Core 4 suggests downhole slumping of the sediment.

Coccoliths are poorly preserved in the upper Eocene sediment of Core 5, and the assemblage suggests deepwater deposition. The remaining cores are Upper Cretaceous and contain sparse assemblages of resistant taxa. On the basis of negative evidence (the lack of certain resistant cosmopolitan Santonian to Maestrichtian taxa such as Micula decussata), samples from Cores 6 to 8 can be considered Cenomanian or Turonian. In Core 12 at 333 meters a representative Cenomanian assemblage is present. It includes Cretarhabdus decorus, Eiffellithus turriseiffeli, Prediscosphaera sp., and Watznaueria sp. aff. W. britannica.

Coccolith Species Considered
Apertapetra gronosa (Stover)
Arkhangelskiella cymbiformis Vekshina
Arkhangelskiella specillata Vekshina
Bidiscus rotatorius Bukry
Braarudosphaera africana Stradner
Braarudosphaera bigelowi (Gran and Braarud)


Braarudosphaera discula Bramlette and Riedel

Braarudosphaera rosa Levin and Joerger

Braarudosphaera turbinea Stradner

Bramletteius serraculoides Gartner

Broinsonia parca (Stradner)

Campylosphaera dela (Bramlette and Sullivan)

Campylosphaera eodela Bukry and Percival

Catinaster calyculus Martini and Bramlette

Catinaster coalitus Martini and Bramlette

Catinaster mexicanus Bukry

Ceratolithus cristatus Kamptner

Ceratolithus rugosus Bukry and Bramlette

Ceratolithus tricorniculatus Gartner

Chiasmolithus altus Bukry and Percival

Chiasmolithus bidens (Bramlette and Sullivan)

Chiasmolithus californicus (Sullivan)

Chiasmolithus consuetus (Bramlette and Sullivan)

Chiasmolithus expansus (Bramlette and Sullivan)

Chiasmolithus gigas (Bramlette and Sullivan)

Chiasmolithus grandis (Bramlette and Riedel)

Chiasmolithus solitus (Bramlette and Sullivan)

Chiastozygus amphipons (Bramlette and Martini)

Chiastozygus bifarius Bukry

Chiastozygus disgregatus (Stover)

Chiphragmalithus calathus Bramlette and Sullivan

Chiphragmalithus cristatus (Martini)

Chiphragmalithus fulgens (Stradner)

basionym: Nannotetraster fulgens Stradner in Martini,

E. and Stradner, H., 1960, Erdoel-Z., 76, p. 268, figs. $10,16$.

Chiphragmalithus quadratus Bramlette and Sullivan

Chiphragmalithus spinosus (Stradner)

Coccolithus crassus Bramlette and Sullivan

Coccolithus cribellum (Bramlette and Sullivan)

Coccolithus doronicoides Black and Barnes

Coccolithus eopelagicus (Bramlette and Riedel)

Coccolithus fenestratus (Deflandre and Fert)

Coccolithus matalosus Stover

Coccolithus pelagicus (Wallich)

Coccolithus pseudogammation Bouché

Coccolithus staurion Bramlette and Sullivan

Corollithion signum Stradner

Cretarhabdus conicus Bramlette and Martini

Cretarhabdus crenulatus Bramlette and Martini

Cretarhabdus decorus (Deflandre)

Cribrosphaera ehrenbergii Arkhangelsky

Cruciplacolithus tenuis (Stradner)

Cyclolithella bramlettei (Hay and Towe)

Cyclolithelld? robusta (Bramlette and Sullivan)

Cyclococcolithina cricota (Gartner)

Cyclococcolithina formosa (Kamptner)

Cyclococcolithina gammation (Bramlette and Sullivan)

Cyclococcolithina leptopora (Murray and Blackman)

Cyclococcolithina macintyrei (Bukry and Bramlette)

basionym: Cyclococcolithus macintyrei Bukry and

Bramlette, 1969, Tulane Stud. Geol. Paleont, v. 7, p.

132, pl. 1, figs. 1-3.

Cyclococcolithina neogammation (Bramlette and Wilcoxon)

Cyclococcolithina protoannula (Gartner)

Cyclococcolithina reticulata (Gartner and Smith)
Cyclococcolithina rotula (Kamptner)

Cylindralithus serratus Bramlette and Martini

Dictyococcites abisectus (Müller)

Dictyococcites bisectus (Hay, Mohler and Wade)

Dictyococcites scrippsae Bukry and Percival

Discoaster araneus Bukry

Discoaster asymmetricus Gartner

Discoaster aulakos Gartner

Discoaster barbadiensis Tan

Discoaster bellus Bukry and Percival

Discoaster berggrenii Bukry

Discoaster bollii Martini and Bramlette

Discoaster braarudii Bukry

Discoaster brouweri Tan

Discoaster calcaris Gartner

Discoaster challengeri Bramlette and Riedel

Discoaster deflandrei Bramlette and Riedel

Discoaster delicatus Bramlette and Sullivan

Discoaster distinctus Martini

Discoaster exilis Martini and Bramlette

Discoaster gemmeus Stradner

Discoaster gemmifer Stradner

Discoaster hamatus Martini and Bramlette

Discoaster kuepperi Stradner

Discoaster lenticularis Bramlette and Sullivan

Discoaster lodoensis Bramlette and Riedel

Discoaster lubinaensis Bystricka

Discoaster mediosus Bramlette and Sullivan

Discoaster mirus Deflandre

Discoaster mohleri Bukry and Percival

Discoaster moorei Bukry

Discoaster multiradiatus Bramlette and Riedel

Discoaster neohamatus Bukry and Bramlette

Discoaster ornatus Stradner

Discoaster pentaradiatus Tan

Discoaster perclarus Hay

Discoaster perplexus Bramlette and Riedel

Discoaster quinqueramus Gartner

Discoaster saipanensis Bramlette and Riedel

Discoaster signus Bukry

Discoaster stradneri Noël

Discoaster sublodoensis Bramlette and Sullivan

Discoaster subsurculus Gartner

Discoaster surculus Martini and Bramlette

Discoaster tani nodifer Bramlette and Riedel

Discoaster tani tani Bramlette and Riedel

Discoaster variabilis pansus Bukry and Percival

Discoaster variabilis variabilis Martini and Bramlette

Discoaster wemmelensis Acuthan and Stradner

Discolithina anisotrema (Kamptner)

Discolithina distincta (Bramlette and Sullivan)

Discolithina japonica Takayama

Discolithina latoculata Bukry and Percival

Discolithina macropora (Deflandre)

Discolithina multipora (Kamptner ex Deflandre)

Discolithina oamaruensis (Deflandre)

Discolithina plana (Bramlette and Sullivan)

Discolithina rimosa (Bramlette and Sullivan)

Discolithina segmenta Bukry and Percival

Discolithina solida (Deflandre)

Discolithina versa (Bramlette and Sullivan) 
Eiffellithus augustus Bukry

Eiffellithus turriseiffeli (Deflandre)

Ellipsolithus distichus (Bramlette and Sullivan)

Ellipsolithus lajollaensis Bukry and Percival

Ellipsolithus macellus (Bramlette and Sullivan)

Emiliania annula (Cohen)

Emiliania huxleyi (Kamptner)

Fasciculithus involutus Bramlette and Sullivan

Fasciculithus tympaniformis Hay and Mohler

Gartnerago concavum (Gartner)

Gartnerago costatum costatum (Gartner)

Gartnerago costatum porolatum Bukry

Gephyrocapsa caribbeanica Boudreaux and Hay

Gephyrocapsa oceanica Kamptner

Helicopontosphaera ampliaperta (Bramlette and Wilcoxon)

Helicopontosphaera compacta (Bramlette and Wilcoxon)

Helicopontosphaera intermedia (Martini)

Helicopontosphaera kamptneri Hay and Mohler

Helicopontosphaera lophota (Bramlette and Sullivan)

Helicopontosphaera obliqua (Bramlette and Wilcoxon)

Helicopontosphaera parallela (Bramlette and Wilcoxon)

Helicopontosphaera reticulata (Bramlette and Wilcoxon)

Helicopontosphaera sellii Bukry and Bramlette

Helicopontosphaera seminulum (Bramlette and Sullivan)

Helicopontosphaera truncata (Bramlette and Wilcoxon)

Helicopontosphaera wallichii (Lohmann)

Helicopontosphaera wilcoxonii Gartner

Heliolithus kleinpelli Sullivan

Heliolithus riedeli Bramlette and Sullivan

Isthmolithus recurvus Deflandre

Lanternithus minutus Stradner

Lithastrinus floralis Stradner

Lithastrinus grilli Stradner

Lophodolithus mochlophorus Deflandre

Lophodolithus nascens Bramlette and Sullivan

Lophodolithus reniformis Bramlette and Sullivan

Lophodolithus rotundus Bukry and Percival

Lucianorhabdus cayeuxi Deflandre

Lucianorhabdus maleformis Reinhardt

Markalius inversus (Deflandre)

Marthasterites furcatus furcatus (Deflandre)

Marthasterites furcatus simplex Bukry

Marthasterites tribrachiatus (Bramlette and Riedel)

Micrantholithus aequalis Sullivan

Micrantholithus attenuatus Bramlette and Sullivan

Micrantholithus basquensis Martini

Micrantholithus fornicatus Martini

Micrantholithus inaequalis Martini

Micrantholithus procerus Bukry and Bramlette

Microrhabdulus decoratus Deflandre

Micula decussata Vekshina

Oolithotus antillarum (Cohen)

Orthozygus aureus (Stradner)

Parhabdolithus angustus (Stradner)

Parhabdolithus embergeri Noël

Pedinocyclus larvalis (Bukry and Bramlette)

Pemma papillatum Martini

Peritrachelina joidesa Bukry and Bramlette

Pontosphaera scutellum Kamptner

Pontosphaera vadosa Hay, Mohler and Wade
Prediscosphaera cretacea (Arkhangelsky)

Prolatipatella multicarinata Gartner

Reticulofenestra gartneri Roth and Hay

Reticulofenestra pseudoumbilica (Gartner)

Reticulofenestra samodurovi (Hay, Mohler and Wade)

Reticulofenestra umbilica (Levin)

Rhabdosphaera clavigera (Murray and Blackman)

Rhabdosphaera inflata Bramlette and Sullivan

Rhabdosphaera morionum (Deflandre)

Rhabdosphaera scabrosa (Deflandre)

Rhabdosphaera spinula Levin

Rhabdosphaera stylifera Lohmann

Rhabdosphaera tenuis Bramlette and Sullivan

Rhabdosphaera truncata Bramlette and Sullivan

Rhomboaster cuspis Bramlette and Sullivan

Scyphosphaera apsteinii Lohmann

Scyphosphaera expansa Bukry and Percival

Scyphosphaera globulata Bukry and Percival

Scyphosphaera intermedia Deflandre

Scyphosphaera pulcherrima Deflandre

Scyphosphaera recurvata Deflandre

Sphenolithus abies Deflandre

Sphenolithus anarrhopus Bukry and Bramlette

Sphenolithus ciperoensis Bramlette and Wilcoxon

Sphenolithus distentus (Martini)

Sphenolithus furcatolithoides Locker

Sphenolithus heteromorphus Deflandre

Sphenolithus moriformis (Brönnimann and Stradner)

Sphenolithus neoabies Bukry and Bramlette

Sphenolithus predistentus Bramlette and Wilcoxon

Sphenolithus pseudoradians Bramlette and Wilcoxon

Sphenolithus radians Deflandre

Stephanolithion laffittei Noël

Syracosphaera fimbriata (Bramlette and Sullivan)

basionym: Discolithus fimbriatus Bramlette and Sul-

livan, 1961, Micropaleontology, v. 7, p. 142, pl. 3, figs. la-d.

Syracosphaera formosa Bukry and Bramlette

Syracosphaera histrica Kamptner

Tetralithus gothicus trifidus Stradner

Thoracosphaera saxea Stradner

Toweius craticulus Hay and Mohler

Toweius eminens (Bramlette and Sullivan)

Transversopontis pulcher (Deflandre)

Transversopontis pulcheroides (Sullivan)

Triquetrorhabdulus carinatus Martini

Triquetrorhabdulus inversus Bukry and Bramlette

Triquetrorhabdulus rugosus Bramlette and Wilcoxon

Umbilicosphaera mirabilis Lohmann

Vagalapilla octoradiata (Gorka)

Vermiculithina arca Bukry and Percival

Watznaueria barnesae (Black)

Watznaueria biporta Bukry

Watznaueria britannica (Stradner)

Zygodiscus adamas Bramlette and Sullivan

Zygodiscus compactus Bukry

Zygodiscus deflandrei Bukry

Zygodiscus gabalus (Stover)

basionym: Tranolithus gabalus Stover, 1966, Micropaleontology, v. 12 , p. 146 , pl. 4 , fig. 22 , pl. 9, fig. 5. 
Zygodiscus lacunatus Gartner

Zygodiscus minimus Bukry

Zygodiscus phacelosus (Stover)

Zygodiscus sigmoides Bramlette and Sullivan

Zygolithus chiastus Bramlette and Sullivan

Zygolithus distentus Bramlette and Sullivan

Zygolithus dubius Deflandre

Zygolithus? ponticulus Deflandre

Zygolithus? variradiatus Stover

Zygrhablithus bijugatus (Deflandre)

Zygrhablithus simplex Bramlette and Sullivan

abies, Sphenolithus

Index of Trivial Names Considered

abisectus, Dictyococcites

adamas, Zygodiscus

aequalis, Micrantholithus

africana, Braarudosphaera

altus, Chiasmolithus

amphipons, Chiastozygus

ampliaperta, Helicopontosphaera

anarrhopus, Sphenolithus

angustus, Parhabdolithus

anisotrema, Discolithina

annula, Emiliania

antillarum, Oolithotus

apsteinii, Scyphosphaera

araneus, Discoaster

arca, Vermiculithina

asymmetricus, Discoaster

attenuatus, Micrantholithus

augustus, Eiffellithus

aulakos, Discoaster

aureus, Orthozygus

barbadiensis, Discoaster

barnesae, Watznaueria

basquensis, Micrantholithus

bellus, Discoaster

berggrenii, Discoaster

bidens, Chiasmolithus

bifarius, Chiastozygus

bigelowi, Braarudosphaera

bijugatus, Zygrhablithus

biporta, Watznaueria

bisectus, Dictyococcites

bollii, Discoaster

braarudii, Discoaster

bramlettei, Cyclolithella?

britannica, Watznaueria

brouweri, Discoaster

calathus, Chiphragmalithus

calcaris, Discoaster

californicus, Chiasmolithus

calyculus, Catinaster

caribbeanica, Gephyrocapsa

carinatus, Triquetrorhabdulus

cayeuxi, Lucianorhabdus

challengeri, Discoaster

chiastus, Zygolithus

ciperoensis, Sphenolithus

clavigera, Rhabdosphaera coalitus, Catinaster

compacta, Helicopontosphaera

compactus, Zygodiscus

concavum, Gartnerago

conicus, Cretarhabdus

consuetus, Chiasmolithus

costatum costatum, Gartnerago

costatum porolatum, Gartnerago

crassus, Coccolithus

craticulus, Toweius

crenulatus, Cretarhabdus

cretacea, Prediscosphaera

cribellum, Coccolithus

cricota, Cyclococcolithina

cristatus, Ceratolithus

cristatus, Chiphragmalithus

cuspis, Rhomboaster

cymbiformis, Arkhangelskiella

decoratus, Microrhabdulus

decorus, Cretarhabdus

decussata, Micula

deflandrei, Discoaster

deflandrei, Zygodiscus

dela, Campylosphaera

delicatus, Discoaster

dilatus, Discoaster

discula, Braarudosphaera

disgregatus, Chiastozygus

distentus, Sphenolithus

distentus, Zygolithus

distichus, Ellipsolithus

distincta, Discolithina

distinctus, Discoaster

doronicoides, Coccolithus

druggii, Discoaster

dubius, Zygolithus

ehrenbergii, Cribrosphaera

embergeri, Parhabdolithus

eminens, Toweius

eodela, Campylosphaera

eopelagicus, Coccolithus

exilis, Discoaster

expansa, Scyphosphaera

expansus, Chiasmolithus

fenestratus, Coccolithus

fimbriata, Syracosphaera

floralis, Lithastrinus

formosa, Cyclococcolithina

formosa, Syracosphaera

fornicatus, Micrantholithus

fulgens, Chiphragmalithus

furcatolithoides, Sphenolithus

furcatus furcatus, Marthasterites

furcatus simplex, Marthasterites

gabalus, Zygodiscus

gammation, Cyclococcolithina

gartneri, Reticulofenestra

gemmeus, Discoaster

gemmifer, Discoaster

gigas, Chiasmolithus

globulata, Scyphosphaera 
gothicus trifidus, Tetralithus grandis, Chiasmolithus grilli, Lithastrinus gronosa, Apertapetra hamatus, Discoaster heteromorphus, Sphenolithus histrica, Syracosphaera huxleyi, Emiliania inaequalis, Micrantholithus inflata, Rhabdosphaera intermedia, Helicopontosphaera intermedia, Scyphosphaera inversus, Markalius inversus, Triquetrorhabdulus involutus, Fasciculithus japonica, Discolithina joidesa, Peritrachelina kamptneri, Helicopontosphaera kleinpelli, Heliolithus kuepperi, Discoaster lacunatus, Zygodiscus laffittei, Stephanolithion lajollaensis, Ellipsolithus larvalis, Pedinocyclus latoculata, Discolithina lenticularis, Discoaster leptopora, Cyclococcolithina lidzi, Discoaster lodoensis, Discoaster lophota, Helicopontosphaera lubinaensis, Discoaster macellus, Ellipsolithus macintyrei, Cyclococcolithina macropora, Discolithina maleformis, Lucianorhabdus matalosus, Coccolithus mediosus, Discoaster mexicanus, Catinaster minimus, Zygodiscus minutus, Lanternithus mirabilis, Umbilicosphaera mirus, Discoaster mochlophorus, Lophodolithus mohleri, Discoaster moorei, Discoaster moriformis, Sphenolithus morionum, Rhabdosphaera multicarinata, Prolatipatella multipora, Discolithina multiradiatus, Discoaster nascens, Lophodolithus neoabies, Sphenolithus neogammation, Cyclococcolithina neohamatus, Discoaster oamaruensis, Discolithina obliqua, Helicopontosphaera oceanica, Gephyrocapsa octoradiata, Vagalapilla ornatus, Discoaster papillatum, Pemma parallela, Helicopontosphaera parca, Broinsonia pelagicus, Coccolithus pentaradiatus, Discoaster perclarus, Discoaster perplexus, Discoaster phacelosus, Zygodiscus plana, Discolithina ponticulus, Zygolithus? predistentus, Sphenolithus procerus, Micrantholithus protoannula, Cyclococcolithina pseudogammation, Cyclococcolithina pseudoradians, Sphenolithus pseudoumbilica, Reticulofenestra pulcher, Transversopontis pulcheroides, Transversopontis pulcherrima, Scyphosphaera quadratus, Chiphragmalithus quinqueramus, Discoaster radians, Sphenolithus recurvata, Scyphosphaera recurvus, Isthmolithus reniformis, Lophodolithus reticulata, Cyclococcolithina reticulata, Helicpontosphaera riedeli, Heliolithus rimosa, Discolithina robusta, Cyclolithella? rosa, Braarudosphaera rotatorius, Bidiscus rotula, Cyclococcolithina rotundus, Lophodolithus rugosus, Ceratolithus rugosus, Triquetrorhabdulus saipanensis, Discoaster samodurovi, Reticulofenestra saxea, Thoracosphaera scabrosa, Rhabdosphaera scrippsae, Dictyococcites scutellum, Pontosphaera segmenta, Discolithina sellii, Helicopontosphaera seminulum, Helicopontosphaera serraculoides, Bramletteius serratus, Cylindralithus serratus, Orthorhabdus sigmoides, Zygodiscus signum, Corollithion signus, Discoaster solida, Discolithina solitus, Chiasmolithus specillata, Arkhangelskiella spinosus, Chiphragmalithus spinula, Rhabdosphaera staurion, Coccolithus stradneri, Discoaster stylifera, Rhabdosphaera sublodoensis, Discoaster subsurculus, Discoaster surculus, Discoaster tani nodifer, Discoaster 
tani tani, Discoaster

tenuis, Cruciplacolithus

tenuis, Rhabdosphaera

tribrachiatus, Marthasterites

tricorniculatus, Ceratolithus

truncata, Helicopontosphaera

truncata, Rhabdosphaera

turbinea, Braarudosphaera

turriseiffeli, Eiffellithus

tympaniformis, Fasciculithus

umbilica, Reticulofenestra

vadosa, Pontosphaera

variabilis pansus, Discoaster

variabilis variabilis, Discoaster

variradiatus, Zygolithus?

versa, Discolithina

wallichii, Helicopontosphaera

wemmelensis, Discoaster

wilcoxonii, Helicopontosphaera

\section{COCCOLITHS IN SELECTED SAMPLES}

\author{
HOLE 85 \\ (lat $22^{\circ} 50.49^{\prime} \mathrm{N}$., long $91^{\circ} 25.37^{\prime} \mathrm{W}$., depth $3749 \mathrm{~m}$ )
}

Holocene

(Emiliania huxleyi Zone)

10-85-1-6, 63-64 cm; depth $27 \mathrm{~m}$;

?E. huxleyi, $H$. kamptneri, $R$. clavigera, $S$. histrica. Reworked Upper Cretaceous taxa: A. cymbiformis, E. turriseiffeli, $M$. decussata, $P$. cretacea, $W$. barnesae

10-85-3-6, 63-64 cm; depth $107 \mathrm{~m}$ :

E. annula, ?E. huxleyi, Gephyrocapsa sp., H. kamptneri,

H. wallichii, Scapholithussp. Reworked Upper Cretaceous taxa: B. parca, C. crenulatus, C. ehrenbergii, E. augustus, $P$. cretacea, $V$. octoradiata, $W$. barnesae, $W$. biporta.

\section{Pleistocene \\ (Gephyrocapsa oceanica Zone)}

10-85-4-1, 62-63 cm; depth $190 \mathrm{~m}$ :

C. leptopora, D. japonica s.l., E. annula, G. oceanica, Gephyrocapsa sp., $H$. kamptneri, $O$. antillarum, $R$. clavigera, $R$. stylifera, Scapholithus sp., $S$. histrica. Reworked Upper Cretaceous and upper Tertiary taxa: D. brouweri s.l., $D$. deflandrei, D. pentaradiatus, $E$. turriseiffeli, $M$. decussata, W. barnesae.

10-85-5-2, 63-64 cm; depth $212 \mathrm{~m}$ :

D. japonica, G. oceanica, $H$. kamptneri, $R$. stylifera, $S$. histrica.

\section{HOLE 86}

(lat $22^{\circ} 52.48^{\prime} \mathrm{N}$., long $90^{\circ} 57.75^{\prime} \mathrm{W}$., depth $1481 \mathrm{~m}$ )

Upper Pleistocene or Holocene

(Upper Gephyrocapsa oceanica Zone or

Emiliania huxleyi Subzone)

10-86-1-1, 63-64 cm; depth $14 \mathrm{~m}$ :

C. cristatus, C. leptopora, D. japonica, D. multipora, ?E. huxleyi, G. oceanica [rare], $H$. kamptneri, $R$. clavigera, $R$. stylifera, Scapholithus sp., S. histrica, Thoracosphaera sp. Reworked Upper Cretaceous taxon: $M$. decussata.

Lower Pleistocene

(Coccolithus doronicoides Zone)

10-86-2-1, 62-63 cm; depth $53 \mathrm{~m}$ :

C. cristatus, C. leptopora, D. japonica, D. macropora, E. annula, $H$. kamptneri, $H$. sellii, $R$. clavigera, $S$. pulcherrima, $S$. recurvata, S. histrica. Reworked Miocene or Pliocene taxa: C. macintyrei, $S$. abies.

\author{
Upper Pliocene \\ (Discoaster brouweri Zone, \\ Discoaster pentaradiatus Subzone)
}

10-86-3-1, 63-64 cm; depth $162 \mathrm{~m}$ :

C. rugosus, C. macintyrei, D. asymmetricus, D. brouweri, D. pentaradiatus, D. surculus, D. variabilis variabilis, $D$. japonica, D. multipora, E. annula, $H$. kamptneri, $H$. sellii, Rhabdosphaerasp., S. apsteinii, S. pulcherrima. Reworked Miocene or Pliocene taxa: D. quinqueramus, $S$. abies.

\section{Lower Pliocene \\ (Reticulofenestra pseudoumbilica Zone, Discoaster asymmetricus Subzone)}

10-86-3-4, 63-64 cm; depth $166 \mathrm{~m}$ :

C. rugosus, C. pelagicus, C. leptopora, C. macintyrei, $D$. asymmetricus, D. brouweri, D. pentaradiatus, $D$. perplexus, D. japonica, D. multipora, R. pseudoumbilica, Rhabdosphaera sp., S. intermedia, $S$. abies, $S$. neoabies.

\section{Upper Miocene \\ (Ceratolithus tricorniculatus Zone)}

10-86-4-1, 63-64 cm; depth $258 \mathrm{~m}$ :

C. tricorniculatus, C. pelagicus [rare], C. leptopora, D. brouweri, D. pentaradiatus, D. surculus, D. variabilis pansus, D. variabilis variabilis, D. japonica, $H$. kamptneri, $R$. pseudoumbilica, Rhabdosphaera sp., S. apsteinii, S. intermedia, $S$. abies, $S$. neoabies, $T$. rugosus.

10-86-4-3, 63-64 cm; depth $261 \mathrm{~m}$ :

C. tricorniculatus, C. macintyrei, C. rotula, D. brouweri, D. pentaradiatus, $D$. surculus, $D$. variabilis pansus, $D$. japonica, H. kamptneri, H. sellii, R. pseudoumbilica, Scyphosphaera sp. cf. $S$. apsteinii, $S$. pulcherrima, $S$. recurvata, $S$. abies, $S$. neoabies, Thoracosphaera sp., T. rugosus. Reworked Oligocene or Miocene taxa: $C$. eopelagicus, $D$. deflandrei.

\section{Middle Oligocene \\ (Sphenolithus distentus Zone)}

10-86-5-1, 101-102 cm; depth $372 \mathrm{~m}$ :

C. eopelagicus, C. neogammation, D. abisectus, D. scrippsae, $D$. deflandrei, $D$. tani nodifer, $H$. intermedia, $S$. distentus, $S$. moriformis, $Z$. bijugatus.

10-86-5-4, 63-64 cm; depth $376 \mathrm{~m}$ : [Same as above].

\section{Upper Paleocene \\ (Discoaster mohleri Zone)}

10-86-7-2, 78-79 cm; depth $500 \mathrm{~m}$ :

$B$. bigelowi, B. rosa, C. californicus, $C$. consuetus, $C$. pelagicus s.l., C. tenuis, C. robustus, Discoaster mohleri, $F$. tympaniformis, $M$. fornicatus, $S$. anarrhopus, $T$. craticulus, $Z$. sigmoides. 
10-86-7-4, 63-64 cm; depth $503 \mathrm{~m}$ :

$B$. bigelowi, $B$. discula, B. rosa, $C$. californicus, $C$. pelagicus s.l., C. robustus, Discoaster mohleri, Ellipsolithus sp. cf. E. distichus, $E$. macellus, $F$. tympaniformis, $M$. fornicatus, $S$. anarrhopus, $T$. craticulus, $Z$. sigmoides.

\section{Upper Paleocene \\ (Heliolithus riedeli Zone)}

10-86-7-5, 63-64 cm; depth $505 \mathrm{~m}$ :

$B$. bigelowi [abundant], C. californicus, Discoaster mohleri, $E$. distichus, $E$. macellus, $F$. tympaniformis, $H$. riedeli [rare], S. anarrhopus, $T$. craticulus, $Z$. chiastus.

\section{Upper Paleocene \\ (Heliolithus kleinpelli Zone)}

10-86-8-1, 143-144 cm; depth $509 \mathrm{~m}$ :

$C$. consuetus, $C$. pelagicus, $C$. robustus, $F$. tympaniformis, $H$. kleinpelli, $S$. anarrhopus, $T$. craticulus, $Z$. chiastus, $Z$. sigmoides.

10-86-8-4, 63-64 cm; depth $513 \mathrm{~m}$ :

$B$. discula, $C$. consuetus, $C$. pelagicus, $C$. tenuis, $F$. tympaniformis, $H$. kleinpelli, $S$. anarrhopus, $T$. craticulus, $Z$. sigmoides, $Z$. simplex.

\section{Lower Paleocene \\ (Cruciplacolithus tenuis Zone)}

10-86-9-1, 63-64 cm; depth $551 \mathrm{~m}$ :

B. bigelowi [abundant], B. discula [abundant] C. pelagicus,

C. tenuis, $M$. fornicatus, Thoracosphaera sp., Z. sigmoides.

\section{HOLE 87 \\ (lat $23^{\circ} 00.90^{\prime} \mathrm{N}$., long $92^{\circ} 05.16^{\prime} \mathrm{W}$., depth $3761 \mathrm{~m}$ )}

Upper Miocene With Reworked Eocene and Oligocene

10-87-1-1, 125-126 cm; depth $649 \mathrm{~m}$ :

C. coalitus, D. brouweri s.l., D. variabilis variabilis, $H$. kamptneri, $R$. pseudoumbilica, $S$. abies. Reworked taxa: $C$. neogammation, $D$. bisectus, $D$. scrippsae, D. saipanensis, $H$. parallela, $R$. umbilica.

\section{HOLE 88 \\ (lat $21^{\circ} 22.93^{\prime} \mathrm{N}$., long $94^{\circ} 00.21^{\prime} \mathrm{W}$., depth $2532 \mathrm{~m}$ ) \\ Holocene \\ (Emiliania huxleyi Zone)}

10-88-1-1, 63-64 cm; depth $1 \mathrm{~m}$ :

C. cristatus, C. leptopora, D. japonica, ?E. huxleyi, G. oceanica, $H$. kamptneri, $H$. sellii, $H$. wallichii, $R$. clavigera, Scapholithus sp., S. apsteinii, S. histrica, Thoracosphaera spp. Reworked taxa: C. crenulatus, D. bisectus, W. barnesae.

\section{Pleistocene \\ (Gephyrocapsa oceanica Zone)}

10-88-1-4, 63-64 cm; depth $5 \mathrm{~m}$ :

C. cristatus, C. leptopora, D. japonica, D. multipora, G. oceanica, Gephyrocapsa sp., $H$. kamptneri, $H$. sellii, $R$. clavigera, $R$. stylifera, Scapholithus sp., S. histrica, Thoracosphaera sp. Reworked taxa: C. neogammation, $W$. barnesae.

\author{
Pleistocene \\ (Coccolithus doronicoides Zone)
}

10-88-2-6, 63-64 cm; depth $59 \mathrm{~m}$ :

C. cristatus, C. leptopora, C. macintyrei, D. japonica, D. multipora, E. annula, G. caribbeanica, H. kamptneri, $H$. sellii, $R$. clavigera, $R$. stylifera, Scapholithus sp., S. pulcherrima, S. histrica, T. saxea. Reworked taxa: C. crenulatus, W. barnesae.

$$
\begin{gathered}
\text { Upper Pliocene } \\
\text { (Discoaster brouweri Zone, } \\
\text { Cyclococcolithus macintyrei Subzone) }
\end{gathered}
$$

10-88-3-3, 73-74 cm; depth $101 \mathrm{~m}$ :

C. macintyrei, D. asymmetricus, D. brouweri, D. japonica, $E$. annula, $H$. kamptneri, $H$. sellii, $H$. wallichii, $R$. clavigera, S. pulcherrima, T. saxea.

$$
\begin{gathered}
\text { Upper Pliocene } \\
\text { (Discoaster brouweri Zone, } \\
\text { Discoaster pentaradiatus Subzone) }
\end{gathered}
$$

10-88-3-6, 70-71 cm; depth $104 \mathrm{~m}$ :

$C$. cristatus, $C$. rugosus, $C$. doronicoides, $C$. leptopora, $C$. macintyrei, $D$. asymmetricus, $D$. brouweri, $D$. pentaradiatus, D. japonica, E. annula, $H$. kamptneri, $H$. sellii, S. apsteinii, Scyphosphaera spp., Thoracosphaera spp.

10-88-4-5, 66-67 cm; depth $107 \mathrm{~m}$ :

C. rugosus, C. leptopora, C. macintyrei, D. asymmetricus, $D$. brouweri, $D$. pentaradiatus, $D$. japonica, $E$. annula s. $l$., $H$. kamptneri, $H$. sellii, $H$. wallichii, S. pulcherrima.

$$
\begin{gathered}
\text { Upper Miocene or Lower Pliocene } \\
\text { (Ceratolithus rugosus Zone) }
\end{gathered}
$$

10-88-5-1, 54-55 cm; depth $128 \mathrm{~m}$ :

Ceratolithus sp. cf. C. cristatus, C. rugosus, C. tricorniculatus, C. leptopora, C. macintyrei, D. brouweri, D. pentaradiatus, $D$. surculus, $D$. variabilis variabilis, $D$. multipora s.l., $H$. kamptneri, $R$. pseudoumbilica, $S$. globulata, $S$. pulcherrima, $S$. neoabies, $T$. saxea.

10-88-5-6, 63-64 cm; depth $131 \mathrm{~m}$ :

C. rugosus, Ceratolithus sp. cf. C. rugosus, C. tricorniculatus, C. macintyrei, D. brouweri, D. brouweri s.l. [large], D. pentaradiatus, D. surculus, D. multipora, $H$. kamptneri, $R$. pseudoumbilica, S. abies.

\section{HOLE 89}

(lat $20^{\circ} 53.41^{\prime} \mathrm{N}$., long $95^{\circ} 06.73^{\prime} \mathrm{W}$., depth $3067 \mathrm{~m}$ )

Holocene

(Emiliania huxleyi Zone)

10-89-1-1, 111-112 cm; depth $1 \mathrm{~m}$ :

C. cristatus [large] C. leptopora, ?E. huxleyi, G. oceanica, $H$. kamptneri, $H$. sellii, $H$. wallichii, $R$. clavigera, Scapholithus sp., S. histrica, Thoracosphaera sp.

$$
\begin{gathered}
\text { Pleistocene } \\
\text { (Gephyrocapsa oceanica Zone) }
\end{gathered}
$$

10-89-1-3, 63-64 cm: depth $4 \mathrm{~m}$ :

C. cristatus, C. leptopora, G. oceanica [abundant], $H$. kamptneri, H. sellii, R. clavigera, Scapholithus sp., S. histrica, Thoracosphaera sp., U. mirabilis. 
Upper Pliocene

(Discoaster brouweri Zone)

10-89-3-1, 63-64 cm; depth $120 \mathrm{~m}$ :

C. cristatus, C. leptopora, C. macintyrei, D. brouweri, $D$. pentaradiatus [abundant], E. annula, $H$. kamptneri, $H$. sellii, $R$. clavigera, $R$. stylifera, S. histrica. Reworked Upper Cretaceous taxa: E. augustus, $M$. decussata, W. barnesae.

Lower Pliocene

(Ceratolithus rugosus Zone)

10-89-4-1, 69-70 cm; depth $220 \mathrm{~m}$ :

C. rugosus, Ceratolithus sp. cf. C. rugosus, C. leptopora, $C$. macintyrei, $D$. asymmetricus [rare], $D$. brouweri, D. pentaradiatus, D. surculus, D. japonica, D. multipora, $H$. kamptneri, $R$. pseudoumbilica, S. globulata, S. pulcherrima, $S$. abies.

10-89-4-3, 63-64 cm; depth $224 \mathrm{~m}$ :

C. rugosus, Ceratolithus sp. cf. C. rugosus, C. tricorniculatus [some bizzare specimens], C. leptopora, $C$. macintyrei, $D$. brouweri, $D$. pentaradiatus, $D$. surculus, $D$. multipora, $H$. kamptneri, $H$. sellii, $R$. pseudoumbilica, $S$. abies.

\section{Upper Miocene \\ (Discoaster quinqueramus Zone)}

10-89-5-1, 117-118 cm; depth $299 \mathrm{~m}$ :

C. macintyrei, $D$. brouweri, D. pentaradiatus, D. quinqueramus, D. surculus, Discoaster sp. cf. D. surculus, $D$. variabilis variabilis, $D$. japonica, $H$. kamptneri, $R$. pseudoumbilica, S. neoabies, T. rugosus. Reworked taxaEocene or Oligocene: $C$. formosa; Paleocene: $C$. tenuis.

10-89-6-1, 99-100 cm; depth $376 \mathrm{~m}$ :

C. tricorniculatus, $D$. brouweri, $D$. pentaradiatus, $D$. quinqueramus, $D$. variabilis variabilis, D. japonica, D. multipora, $H$. kamptneri, $R$. pseudoumbilica, Rhabdosphaera sp., $S$. abies. Reworked taxa-Cretaceous: $C$. ehrenbergii, $W$. barnesae; Eocene: $C$. reticulata, D. bisectus, $L$. nascens, R. umbilica.

\section{HOLE 90}

(lat $23^{\circ} 47.80^{\prime}$ W., long $94^{\circ} 46.09^{\prime} \mathrm{N}$., depth $3713 \mathrm{~m}$ )
Zone)

\section{Holocene \\ (Emiliania huxleyi Zone)}

10-90-1-1, 63-64 cm; depth $1 \mathrm{~m}$ :

C. cristatus [large, robust specimens], $C$. leptopora, $D$. japonica, ? E. huxleyi, G. oceanica, H. kamptneri, H. sellii, $H$. wallichii, $R$. clavigera, $S$. histrica, Thoracosphaera sp., $U$. mirabilis.

\section{Upper Pleistocene \\ (Gephyrocapsa oceanica Zone)}

10-90-1-6, 63-64 cm; depth $8 \mathrm{~m}$ :

C. cristatus, D. japonica, D. multipora s. l., G. caribbeanica, G. oceanica [abundant], H. kamptneri, $R$. clavigera, Scapholithus sp.

\author{
Lower Pleistocene \\ (Coccolithus doronicoides Zone)
}

10-90-2-1, 63-64 cm; depth $71 \mathrm{~m}$ :

C. cristatus, C. leptopora, D. japonica, E. annula, G. caribbeanica, $H$. kamptneri, $H$. sellii, $R$. clavigera, $R$. stylifera, Scapholithus sp., S. pulcherrima, S. recurvata, $S$. histrica, T. saxea, U. mirabilis. Reworked taxa-Upper Cretaceous: Z. deflandrei; Miocene: D. bollii.

10-90-2-4, 63-64 cm; depth $75 \mathrm{~m}$ :

C. cristatus, C. pelagicus, C. leptopora, D. multipora s. l., E. annula, Gephyrocapsa sp. cf. G. caribbeanica, H. kamptneri, Scapholithus sp., S. pulcherrima, S. histrica. Reworked Eocene or Oligocene taxon: $C$. formosa.

\section{Upper Pliocene \\ (Discoaster brouweri Zone)}

10-90-3-1, 63-64 cm; depth $130 \mathrm{~m}$ :

$C$. rugosus, C. pelagicus, C. leptopora, $C$. macintyrei, D. asymmetricus, $D$. brouweri, $D$. pentaradiatus, $D$. japonica, E. annula, $H$. kamptneri, $H$. sellii, $R$. clavigera, $S$. pulcherrima, Syracosphaera sp.

10-9-3-3, 63-64 cm; depth $133 \mathrm{~m}$ :

Ceratolithus sp. cf. C. cristatus, C. doronicoides, C. pelagicus, C. leptopora, C. macintyrei, D. asymmetricus, D. brouweri, D. pentaradiatus, Discoaster sp. cf. D. surculus, $H$. sellii, Scyphosphaera sp., T. saxea. Reworked Upper Cretaceous taxa: E. turriseiffeli, $\boldsymbol{W}$. barnesae.

\section{Upper Miocene or Lower Pliocene (Ceratolithus rugosus Zone)}

10-90-4-1, 103-104 cm; depth $188 \mathrm{~m}$ :

Ceratolithus sp. cf. C. rugosus, C. tricorniculatus, C. leptopora, C. macintyrei, D. brouweri, Discoaster sp. aff. D. brouweri [large] D. pentaradiatus, D. surculus, H. kamptneri [rare] $R$. pseudoumbilica [some specimens mimic $D$. bisectus] $S$. abies, $S$. neoabies.

10-90-4-3, 63-64 cm; depth $191 \mathrm{~m}$ :

Ceratolithus sp. cf. C. rugosus, C. tricorniculatus, C. leptopora, D. brouweri, D. pentaradiatus, D. surculus, $H$. kamptneri, $R$. pseudoumbilica, S. abies, S. neoabies.

\section{Upper Miocene \\ (Discoaster quinqueramus Zone)}

10-90-5-1, 63-64 cm; depth $237 \mathrm{~m}$ :

C. tricorniculatus [rare] C. macintyrei, D. brouweri s.l., Discoastersp. cf. D. exilis [webbed rays], $D$. pentaradiatus, $D$. quinqueramus, Discoaster sp. cf. $D$. surculus, $D$. variabilis, $R$. pseudoumbilica, $S$. abies, $T$. rugosus. Reworked Upper Cretaceous taxon: $M$. decoratus.

10-90-6-2, 63-64 cm; depth $295 \mathrm{~m}$ :

C. pelagicus, $D$. berggrenii, $D$. brouweri, $D$. quinqueramus, D. variabilis variabilis, $D$. multipora, $S$. abies, $T$. rugosus. Reworked Upper Cretaceous taxa: $C$. crenulatus, $\boldsymbol{W}$. barnesae.

10-90-7-2, 63-64 cm; depth $343 \mathrm{~m}$ :

C. pelagicus, D. brouweri, D. quinqueramus, D. variabilis pansus, $D$. variabilis variabilis, $H$. sellii, $S$. abies. Reworked 
taxa-Upper Cretaceous: $P$. cretacea, $W$. barnesae; Eocene: C. eopelagicus, $D$. barbadiensis, $R$. umbilica.

Upper Miocene

(? Zone)

10-90-9-1, 59-60 cm; depth $472 \mathrm{~m}$ :

Catinaster $\mathrm{sp}$. cf. C. calyculus, C. pelagicus, C. macintyrei, Discoaster sp. aff. D. brouweri [large, 5- and 6-rayed], $D$. variabilis variabilis, $D$. japonica, D. multipora, $H$. kamptneri, $R$. pseudoumbilica. Reworked taxa-Upper Cretaceous: C. ehrenbergii, $M$. decussata, W. barnesae; Eocene: D. lodoensis.

10-90-10-1, 52-53 cm; depth $596 \mathrm{~m}$ :

C. pelagicus, D. variabilis variabilis, $H$. kamptneri, $R$. pseudoumbilica. Reworked Upper Cretaceous taxa: $C$. crenulatus, $M$. decussata, $W$. barnesae.

\section{Upper Miocene \\ (Catinaster coalitus Zone)}

10-90-11-2, 63-64 cm; depth $677 \mathrm{~m}$ :

$C$. coalitus, C. mexicanus, C. eopelagicus, $C$. macintyrei, $C$. rotula, D. bollii, D. brouweri s.l., D. signus, $H$. kamptneri, $R$. pseudoumbilica, $S$. neoabies. Reworked taxa-Upper Cretaceous: $E$. turriseiffeli, $Z$. deflandrei; Eocene: $D$. barbadiensis.

10-90-11-6, 63-64 cm; depth $682 \mathrm{~m}$ :

C. coalitus, $C$. mexicanus, $C$. eopelagicus, $C$. lepropora, $D$. bollii, $D$. braarudii, $D$. deflandrei, $D$. variabilis variabilis, H. kamptneri, $R$. pseudoumbilica, S. abies, S. neoabies.

\section{Middle Miocene \\ (Discoaster exilis Zone)}

10-90-13-1, 62-63 cm; depth $764 \mathrm{~m}$ :

C. eopelagicus, C. pelagicus, C. leptopora, C. macintyrei, $C$. rotula, $D$. bollii, $D$. braarudii, $D$. exilis, $D$. subsurculus, $D$. variabilis variabilis, D. multipora, $H$. kamptneri, $R$. pseudoumbilica, Rhabdosphaera sp. Reworked Upper Cretaceous taxa: E. turriseiffeli, W. barnesae.

$$
\begin{gathered}
\text { HOLE } 91 \\
\text { (lat } 23^{\circ} 46.40^{\prime} \mathrm{N} \text {., long } 93^{\circ} 20.77^{\prime} \mathrm{W} \text {., depth } 3763 \mathrm{~m} \text { ) }
\end{gathered}
$$

Upper Pleistocene or Holocene

10-91-1-1, 100-101 cm; depth $61 \mathrm{~m}$ :

G. oceanica, H. kamptneri. Reworked Upper Cretaceous taxa: B. parca, C. ehrenbergii, P. cretacea, W. barnesae.

10-91-2-5, 63-64 cm; depth $132 \mathrm{~m}$ :

C. leptopora, D. japonica, G. oceanica, H. kamptneri, $H$. wallichii, $R$. clavigera. Reworked Upper Cretaceous taxon: A. cymbiformis.

10-91-3-6, 63-64 cm; depth $167 \mathrm{~m}$ :

H. kamptneri. Reworked taxa-Upper Cretaceous: $E$. turriseiffeli, $G$. costatum porolatum, $M$. decussata, $P$. cretacea; upper Tertiary: $R$. pseudoumbilica, S. abies.

10-91-7-5, 62-63 cm; depth $413 \mathrm{~m}$ :

C. leptopora, Gephyrocapsa sp., H. kamptneri, H. sellii, $R$. clavigera, Thoracosphaera sp. Reworked Upper Creta- ceous taxa: $C$. crenulatus, $E$. augustus, $E$. turriseiffeli, $M$. decussata, $P$. cretacea, $V$. octoradiata, $W$. barnesae.

\section{Pliocene or Pleistocene \\ (Transitional)}

10-91-8-2, 63-64 cm; depth $492 \mathrm{~m}$ :

C. cristatus, C. doronicoides, C. leptopora, C. macintyrei, D. brouweri [rare], D. japonica, E. annula, H. kamptneri, $H$. sellii, $R$. clavigera, Scapholithus sp., $S$. apsteinii, $S$. pulcherrima, S. histrica, U. mirabilis. Reworked Upper Cretaceous taxa: $M$. decussata, $P$. cretacea.

$$
\begin{gathered}
\text { Upper Pliocene } \\
\text { (Discoaster brouweri Zone, } \\
\text { Discoaster pentaradiatus Subzone) }
\end{gathered}
$$

10-91-9-6, 63-64 cm; depth $538 \mathrm{~m}$ :

C. rugosus, C. leptopora, C. macintyrei, D. asymmetricus, D. brouweri, D. pentaradiatus, D. japonica, E. annula, $H$. kamptneri, $H$. sellii, $H$. wallichii, $R$. clavigera, S. pulcherrima.

\section{Upper Miocene \\ (Discoaster quinqueramus Zone)}

10-91-10-2, 63-64 cm; depth $653 \mathrm{~m}$ :

C. pelagicus, $C$. rotula, $D$. berggrenii, $D$. braarudii, $D$. brouweri, $D$. pentaradiatus, $D$. quinqueramus, $D$. variabilis variabilis, H. kamptneri, $R$. pseudoumbilica, Sphenolithus ? sp. aff. S. neoabies. Reworked taxa-Upper Cretaceous: $M$. decussata, $W$. barnesae; Eocene: D. barbadiensis.

Middle Miocene or Upper Miocene

10-91-11-2, 63-64 cm; depth $772 \mathrm{~m}$ :

C. pelagicus, Discoaster sp., H. kamptneri, R. pseudoumbilica.

10-91-14-2, 63-64 cm; depth $800 \mathrm{~m}$ :

C. pelagicus, $C$. rotula, $D$. variabilis variabilis, $H$. kamptneri, $R$. pseudoumbilica, $S$. neoabies. Reworked taxaUpper Cretaceous: $W$. barnesae; Eocene: $C$. dela, $D$. mirus.

10-91-16-3, 63-64 cm; depth $819 \mathrm{~m}$ :

C. pelagicus, C. leptopora, D. brouweri s. l., D. variabilis variabilis, D. multipora, $H$. kamptneri, $R$. pseudoumbilica, S. neoabies. Reworked taxa-Upper Cretaceous: $A$. cymbiformis, $E$. turriseiffeli, $M$. decussata, $W$. barnesae; Eocene or Oligocene: $C$. neogammation, $D$. bisectus, $H$. parallela, I. recurvus, $M$. attenuatus.

10-91-18-6, 95-96 cm; depth $843 \mathrm{~m}$ :

D. bollii, D. variabilis variabilis, $H$. kamptneri, $R$. pseudoumbilica, $S$. neoabies. Reworked Eocene or Oligocene taxa: C. formosa, R. umbilica.

10-91-22-2, 63-74 cm; depth $868 \mathrm{~m}$ :

C. leptopora, D. variabilis variabilis, $R$. pseudoumbilica.

10-91-25-4, 63-64 cm; depth $896 \mathrm{~m}$ :

C. eopelagicus, C. pelagicus, C. leptopora, $C$. macintyrei, $D$. variabilis variabilis, D. multipora, $H$. kamptneri, $R$. pseudoumbilica. Reworked Cretaceous taxon: $W$. barnesae. 
HOLE 92

(lat $25^{\circ} 50.69^{\prime} \mathrm{N}$., long $91^{\circ} 49.29^{\prime} \mathrm{W}$., depth $2573 \mathrm{~m}$ )

Pleistocene or Holocene

10-92-2-5, 63-64 cm; depth $38 \mathrm{~m}$ :

G. oceanica, Gephyrocapsa sp. [small]. Reworked taxaUpper Cretaceous: A. cymbiformis, A. specillata, $C$. crenulatus, $C$. ehrenbergii, E. turriseiffeli, $G$. costatum costatum, $M$. decussata, $P$. cretacea, $V$. octoradiata; Miocene or Pliocene: S. abies.

10-92-3-5, 64-65 cm; depth $94 \mathrm{~m}$ :

Gephyrocapsa sp. [small]. Reworked Upper Cretaceous taxa: A. cymbiformis, $C$. ehrenbergii, $E$. turriseiffeli, $M$. decussata, P. cretacea, W. barnesae, Zygodiscus $\mathrm{sp}$.

10-92-4-5, 62-63 cm; depth $132 \mathrm{~m}$ :

Discolithina sp. cf. D. japonica, G. oceanica, Gephyrocapsa sp. [small]. Reworked Upper Cretaceous taxon: M. decussata.

\section{Lower Pleistocene \\ (Coccolithus doronicoides Zone)}

10-92-5-6, 63-64 cm; depth $180 \mathrm{~m}$ :

E. annula, G. carribeanica, $H$. kamptneri, $S$. histrica. Reworked Upper Cretaceous taxa: A. cymbiformis, B. parca, $C$. crenulatus, $C$. ehrenbergii, E. turriseiffeli, $L$. floralis, $M$. decussata, $P$. augustus, $P$. cretacea, V. octoradiata, W. barnesae.

\section{Miocene, Pliocene, or Pleistocene}

10-92-6-2, 63-64 cm; depth $222 \mathrm{~m}$ :

C. pelagicus, H. kamptneri. Reworked Upper Cretaceous taxa: E. turriseiffeli, $M$. decussata, P. cretacea, W. barnesae.

\section{Series Unknown}

10-92-7-1, 129-130 cm; depth $258 \mathrm{~m}$ :

[barren].

10-92-8-1, 63-64 cm; depth $262 \mathrm{~m}$.

[barren].

\section{HOLE 93}

(lat $22^{\circ} 37.25^{\prime} \mathrm{N}$., long $91^{\circ} 28.78^{\prime} \mathrm{W}$., depth $3090 \mathrm{~m}$ )

\author{
Holocene \\ (Emiliania huxleyi Zone)
}

10-93-1-1, 128-129 cm; depth $0 \mathrm{~m}$ :

C. cristatus [large], C. pelagicus, C. leptopora, D. multipora s.l., ?E. huxleyi, G. oceanica, H. kamptneri, H. wallichii, $R$. clavigera, Rhabdothorax sp., S. histrica, Thoracosphaera sp.

\section{Upper Miocene \\ (Discoaster quinqueramus Zone)}

10-93-1-2, 65-67 cm; depth $1 \mathrm{~m}$ :

C. triconiculatus [rare] C. pelagicus, C. leptopora, C. macintyrei, $D$. berggrenii, $D$. brouweri, $D$. pentaradiatus, $D$. quinqueramus, D. surculus, D. variabilis, $H$. kamptneri, $R$. pseudoumbilica, S. neoabies, T. rugosus.
HOLE 94

(lat $24^{\circ} 31.64^{\prime} \mathrm{N}$., long $88^{\circ} 28.16^{\prime}$ w., depth $1793 \mathrm{~m}$ )

Upper Pleistocene

(Gephyrocapsa oceanica Zone)

10-94-1-2, 63-64 cm; depth $1 \mathrm{~m}$ :

C. leptopora, D. japonica, D. multipora s.l., G. oceanica, $H$. kamptneri, $H$. sellii, $H$. wallichii, $R$. clavigera, Rhabdothorax sp., Scapholithus sp., S. apsteinii, S. histrica, Thoracosphaera sp.

\section{Upper Pliocene \\ (Discoaster brouweri Zone, Discoaster pentaradiatus Subzone)}

10-94-2-1, 63-64 cm; depth $53 \mathrm{~m}$ :

C. rugosus, C. leptopora, C. macintyrei, D. asymmetricus, $D$. brouweri, $D$. pentaradiatus, $D$. perplexus, $D$. surculus, $D$. japonica, E. annula, $H$. kamptneri, $R$. clavigera, $S$. histrica.

\section{Lower Pliocene \\ (Reticulofenestra pseudoumbilica Zone, Discoaster asymmetricus Subzone)}

10-94-3-1, 63-64 cm; depth $101 \mathrm{~m}$ :

C. rugosus, C. leptopora, C. macintyrei, D. asymmetricus, $D$. brouweri, $D$. pentaradiatus, $D$. surculus, $D$. variabilis pansus, D. japonica, D. multipora, H. kamptneri, $H$. sellii, Rhabdosphaera sp., $R$. pseudoumbilica, S. pulcherrima, $S$. abies, $S$. neoabies.

10-94-3-6, 63-64 cm; depth $108 \mathrm{~m}$ :

C. rugosus, $C$. macintyrei, $C$. rotula, $D$. asymmetricus, $D$. brouweri, $D$. pentaradiatus [abundant], $D$. perplexus, $D$. surculus, D. japonica, H. kamptneri, H. sellii, Rhabdosphaera sp., R. pseudoumbilica, S. globulata, S. pulcherrima, Scyphosphaera spp., $S$. neoabies, $S$. histrica, Thoracosphaera sp.

\section{Upper Miocene or Lower Pliocene (Ceratolithus rugosus Zone)}

10-94-4-1, 63-64 cm; depth $130 \mathrm{~m}$ :

C. rugosus, Ceratolithus sp. cf. C. rugosus, C. tricorniculatus, $C$. leptopora, C. macintyrei, $C$. rotula, $D$. brouweri, $D$. pentaradiatus, $D$. surculus, $D$. japonica, $D$. multipora, $H$. kamptneri, $H$. sellii, $R$. pseudoumbilica, $S$. pulcherrima, $S$. neoabies.

10-94-4-6, 60-61 cm; depth $137 \mathrm{~m}$ :

C. rugosus, C. tricorniculatus, C. macintyrei, $C$. rotula, $D$. brouweri, $D$. pentaradiatus [abundant], $D$. surculus, $D$. japonica, D. multipora s.l., H. kamptneri, R. pseudoumbilica, S. apsteinii, S. globulata, S. pulcherrima, S. abies, $S$. neoabies [abundant].

\section{Upper Miocene \\ (Ceratolithus tricorniculatus Zone)}

10-94-5-1, 63-64 cm; depth $169 \mathrm{~m}$ :

C. tricorniculatus, C. pelagicus, C. macintyrei, C. rotula, $D$. challengeri, $D$. pentaradiatus, $D$. quinqueramus [rare], $D$. surculus, D. japonica, H. kamptneri, $R$. pseudoumbilica, Rhabdosphaera sp., S. globulata, S. abies, S. neobies, $T$, rugosus [rare]. 
Upper Miocene

(Discoaster quinqueramus Zone)

10-94-5-6, 63-64 cm; depth $176 \mathrm{~m}$ :

C. tricorniculatus, C. pelagicus, C. leptopora, D. brouweri, $D$. challengeri, $D$. pentaradiatus, D. quinqueramus [common], $D$. surculus, $D$. variabilis variabilis, $D$. japonica, $H$. kamptneri, $R$. pseudoumbilica, S. globulata, S. pulcherrima, $S$. abies [abundant], $S$. neoabies, $T$. rugosus.

10-94-6-6, 63-64 cm; depth $215 \mathrm{~m}$ :

$C$. pelagicus, C. cricotus, C. macintyrei, C. rotula, D. brouweri, $D$. pentaradiatus, $D$. quinqueramus, $D$. surculus, $D$. variabilis variabilis, $H$. kamptneri, $S$. abies, $S$. neoabies.

10-94-7-5, 63-64 cm; depth $248 \mathrm{~m}$ :

C. pelagicus, C. leptopora, C. rotula, D. brouweri, D. quinqueramus, $D$. surculus, $D$. variabilis pansus, $D$. variabilis variabilis, $H$. kamptneri, $H$. sellii, $S$. abies, $S$. neoabies.

10-94-8-3, 63-64 cm; depth $254 \mathrm{~m}$ :

$C$. pelagicus, $C$. leptopora, D. berggrenii, D. brouweri s.l., $D$. quinqueramus, $D$. surculus, $D$. variabilis variabilis, $D$. japonica s.l., H. kamptneri, S. abies, S. neoabies, T. rugosus.

10-94-8-5, 63-64 cm; depth $256 \mathrm{~m}$ :

$C$. pelagicus, $C$. leptopora [rare], D. berggrenii [abundant], $D$. brouweri s.l., D. challengeri, D. pentaradiatus, $D$. surculus, D. japonica, D. multipora, H. kamptneri, H. sellii, Scyphosphaera sp. cf. S. globulata, S. pulcherrima, S. abies [abundant], Thoracosphaera sp., T. rugosus.

\section{Lower Miocene \\ (Helicopontosphaera ampliaperta Zone)}

10-94-9-1, 63-64 cm; depth $293 \mathrm{~m}$ :

C. eopelagicus, $C$. leptopora [rare], C. neogammation, D. aulakos, D. deflandrei [abundant], Discoaster sp. cf. D. exilis, $D$. anisotrema, $H$. ampliaperta, $H$. kamptneri, $R$. pseudoumbilica, Scyphosphaera sp., S. heteromorphus, $S$. moriformis.

10-94-9-6, 63-64 cm; depth $300 \mathrm{~m}$ :

C. eopelagicus, C. neogammation, Discoaster sp. cf. D. aulakos, D. deflandrei, Discolithina sp. aff. D. japonica, $H$. ampliaperta, R. pseudoumbilica [rare], S. heteromorphus.

Lower Miocene

(Triquetrorhabdulus carinatus Zone,

Dictyococcites abisectus Subzone)

10-94-10-1, 79-80 cm; depth $331 \mathrm{~m}$ :

C. eopelagicus, C. neogammation, D. abisectus, D. scrippsae, D. deflandrei, D. multipora s.l., H. obliqua, H. parallela, $S$. dissimilis, $S$. moriformis, $R$. gartneri, Rhabdothorax sp., Thoracosphaera sp.

Middle Oligocene

(Sphenolithus predistentus Zone)

10-94-11-6, 63-64 cm; depth $369 \mathrm{~m}$ :

C. eopelagicus, C. neogammation, D. abisectus, D. bisectus, $D$. scrippsae, $D$. deflandrei, $D$. tani tani, $H$. compacta, $H$. intermedia, O. aureus, $P$. joidesa, R. gartneri, Sphenolithus sp. cf. $S$. distentus, $S$. moriformis, $S$. predistentus, Thoracosphaera sp., Z. bijugatus.
10-94-12-4, 59-60 cm; depth $374 \mathrm{~m}$ :

C. eopelagicus, C. neogammation, D. bisectus, D. scrippsae, $D$. deflandrei, $D$. tani, tani, $H$. parallela, $P$. vadosa, $R$. gartneri, S. predistentus, $Z$. bijugatus.

10-94-13-3, 100-102 cm; depth $381 \mathrm{~m}$ :

C. eopelagicus, $C$. neogammation, D. bisectus, D. scrippsae, $D$. deflandrei, $D$. tani tani, $H$. compacta, $L$. minutus, $P$. joidesa, $R$. gartneri, ?R. tenuis [stems], $S$, distentus [rare], $S$. moriformis, $S$. predistentus, Thoracosphaera sp., $Z$. bijugatus.

10-94-14-1, 30-32 cm; depth $407 \mathrm{~m}$ :

$B$. rosa, B. serraculoides, $C$. eopelagicus, D. bisectus, $D$. scrippsae, D. deflandrei, D. tani tani, $H$. compacta, Helicopontosphaera sp. cf. $H$. intermedia, $H$. reticulata, L. minutus, P. vadosa, ?R. tenuis [stems], S. moriformis, $S$. predistentus, $Z$. bijugatus.

\section{Upper Eocene \\ (Discoaster barbadiensis Zone)}

10-94-14-1, 122-123 cm; depth $408 \mathrm{~m}$ :

$B$. discula, B. rosa, B. serraculoides, $C$. eopelagicus, $C$. pseudogammation, $C$. formosa, $C$. neogammation, $C$. reticulata, $D$. scrippsae, $D$. barbadiensis, $D$. deflandrei, $D$. saipanensis, D. tani nodifer, D. tani tani, $H$. compacta, $H$. reticulata, $I$. recurvus [rare], $P$. papillatum, $P$. joidesa, $R$. umbilica, S. predistentus, Z. bijugatus.

10-94-14-3, 63-64 cm; depth $411 \mathrm{~m}$ :

$B$. bigelowi, B. serraculoides, C. eopelagicus, C. formosa, C. neogammation, $C$. reticulata, D. scrippsae, D. barbadiensis, D. saipanensis, I. recurvus [rare], M. aequalis, $R$. umbilica.

10-94-14-4, 62-63 cm; depth $413 \mathrm{~m}$ :

$B$. bigelowi, $B$. rosa, B. serraculoides, $C$. oamaruensis, $C$. formosa, C. neogammation, C. protoannula, C. reticulata, D. scrippsae, D. barbadiensis, D. saipanensis, D. tani tani, $H$. compacta, $H$. reticulata, Micrantholithus sp., P. papillatum, $P$. joidesa, $R$. umbilica, $S$. predistentus, $Z$. bijugatus.

10-94-15-4, 75-76 cm; depth $417 \mathrm{~m}$ :

B. bigelowi, B. serraculoides, $C$. eopelagicus, $C$. formosa, $C$. neogammation, $C$. reticulata [abundant], D. bisectus, $D$. scrippsae, $D$. barbadiensis, $D$. saipanensis, $D$. tani tani, $H$. compacta, $H$. reticulata, $I$. recurvus [rare], $M$. inversus, $P$. vadosa, $R$. umbilica, Z. bijugatus.

10-94-16-1, 63-64 cm; depth $419 \mathrm{~m}$ :

B. bigelowi, B. serraculoides, C. dela [rare], C. eopelagicus, C. formosa, C. neogammation, $C$. protoannula, $C$. reticulata, $D$. bisectus, $D$. barbadiensis, $D$. saipanensis, $D$. tani nodifer, $D$. tani tani, $H$. compacta, $H$. reticulata, $M$. aequalis, $R$. umbilica, V. arca [rare], Z. bijugatus.

10-94-16-3, 63-64 cm; depth $422 \mathrm{~m}$ :

$B$. bigelowi, B. discula [large] B. serraculoides, C. eopelagicus, $C$. formosa, C. neogammation, $C$. protoannula, $C$. reticulata, $D$. bisectus, $D$. scrippsae, $D$. barbadiensis, $D$. saipanensis [some specimens mimic $D$. lodoensis], $D$. tani nodifer, $D$. tani tani, $H$. compacta, $H$. reticulata, $M$. inver- 
sus, $M$. aequalis, $P$. papillatum, $P$. vadosa, $R$. samodurovi, S. pseudoradians, $Z$. bijugatus.

Middle Eocene

(Lower Reticulofenestra umbilica Zone)

10-94-17-1, 17-18 cm; depth $424 \mathrm{~m}$ :

B. discula, B. rosa, B. serraculoides, $C$. dela, C. grandis, $C$. cribellum, C. eopelagicus, $C$. staurion, $D$. barbadiensis, $D$. deflandrei, $H$. compacta, $M$. procerus, $R$. samodurovi, $S$. furcatolithoides, S. pseudoradians, T. inversus. Reworked Eocene taxon: D. mirus.

10-94-17-2, $63-64 \mathrm{~cm}$; depth $426 \mathrm{~m}$ :

$B$. discula, B. serraculoides, $C$. dela, $C$. grandis, C. solitus, C. staurion, C. formosa, D. barbadiensis, Discoaster sp. cf. $D$. deflandrei, $M$. inversus, $M$. procerus, $R$. samodurovi, $S$. furcatolithoides, $T$. inversus.

10-94-17-5, 6-7 cm; depth $430 \mathrm{~m}$ :

$B$. discula, B. serraculoides, $C$. dela, $C$. grandis, $C$. solitus, C. cribellum, C. eopelagicus, C. formosa, Cyclococcolithina sp. cf. C. neogammation, D. barbadiensis, Discoastersp. cf. $D$. deflandrei, D. gemmifer [4-rayed], D. stradneri, $H$. compacta, M. procerus, $R$. samodurovi, S. furcatolithoides, T. inversus, Z. bijugatus.

\section{Middle Eocene (Chiphragmolithus quadratus Zone)}

10-94-18-1, 63-64 cm; depth $434 \mathrm{~m}$ :

B. discula [abundant], B. serraculoides, C. dela, C. grandis, $C$. solitus, C. quadratus, C. eopelagicus, C. pseudogammation, C. staurion, C. formosa, D. barbadiensis, Discoaster, sp. cf. $D$. deflanderi, $D$. wemmelensis, $D$. oamaruensis, $D$. plana, $H$. compacta, $M$. procerus, $P$. larvalis, $R$. samodurovi, S. furcatolithoides, $T$. inversus, $Z$. bijugatus.

10-94-18-4, 63-64 cm; depth $438 \mathrm{~m}$ :

$B$. discula, B. rosa, $B$. serraculoides [small], $C$. dela, $C$. grandis, $C$. solitus, $C$. spinosus, $C$. pseudogammation, $C$. staurion, $C$. formosa, D. barbadiensis, Discoaster sp. cf. D. deflandrei, D. tani nodifer, $H$. compacta, M. aequalis, $R$. samodurovi, $T$. inversus, $Z$. bijugatus.

10-94-19-2, 65-66 cm; depth $444 \mathrm{~m}$ :

B. bigelowi, B. discula, C. dela, C. grandis, C. spinosus, $C$. staurion, $C$. formosa, D. barbadiensis, Discoaster sp. cf. $D$. deflandrei, $D$. tani nodifer, $D$. wemmelensis, $H$. lophota, $R$. samodurovi, S. radians, $T$. inversus, $Z$. bijugatus.

10-94-19-5, 63-64 cm; depth $448 \mathrm{~m}$ :

B. discula, B. rosa, C. dela, C. gigas, C. grandis, Ch. cristatus, $C$. pseudogammation, C. staurion, C. bramlettei, $C$. formosa, $D$. barbadiensis, $D$. distinctus, $D$. tani nodifer, $D$. wemmelensis, Helicopontosphaera sp. cf. $H$. lophota, $H$. seminulum, M. aequalis, $R$. samodurovi, S. furcatolithoides, $S$. radians, $S$. fimbriata, $T$. inversus, $Z$. bijugatus.

10-94-20-3, 67-68 cm; depth $445 \mathrm{~m}$ :

B. discula, B. rosa, C. dela, C. gigas, C. grandis, C. solitus, Ch. cristatus, C. bramlettei, C. formosa, D. barbadiensis, $D$. distinctus, $D$. stradneri, $D$. tani nodifer, $D$. wemmelensis, D. plana, H. seminulum, $R$. samodurovi [some speci- mens resemble $D$. scrippsae], $S$. furcatolithoides, $S$. radians, $T$. inversus, $Z$. bijugatus.

10-94-21-2, 0-2 cm; depth $462 \mathrm{~m}$ :

B. discula, B. rosa, C. dela, C. gigas, C. grandis, C. solitus, Ch. cristatus, Chiphragmalithus sp. cf. C. quadratus, $C$. bramlettei, $C$. formosa, $D$. distinctus, D. mirus, $H$. lophota, $H$. seminulum, L. rotundus, Rhabdosphaera sp. cf. R. scabrosa, S. furcatolithoides, Thoracosphaera sp., T. inversus.

Middle Eocene

(Discoaster sublodoensis Zone)

10-94-22-1, 63-64 cm; depth $470 \mathrm{~m}$ :

$B$. discula, B. rosa [large], C. grandis, $C$. eopelagicus, $C$. formosa, $D$. barbadiensis, $D$. lodoensis, $D$. stradneri, $D$. sublodoensis, $D$. tani nodifer, $R$. samodurovi, $S$. radians, $T$. inversus, $Z$. bijugatus.

10-94-22-2, 63-64 cm; depth $471 \mathrm{~m}$ :

$B$. discula, C. dela, C. solitus, C. staurion, C. formosa, D. barbadiensis, $D$. distinctus, $D$. lodoensis, $D$. sublodoensis, T. inversus, $Z$. dubius.

10-94-23-1, 93-94 cm; depth $479 \mathrm{~m}$ :

B. discula, B. rosa, C. dela, C. grandis, C. solitus, $C$. eopelagicus, C. pseudogammation, C. staurion, C. bramlettei, $C$. formosa, D. barbadiensis, D. distinctus, D. lodoensis, $D$. tani nodifer, $H$. lophota, $H$. seminulum, $R$. inflata, $S$. radians, Syracosphaera sp. cf. $S$. formosa, T. inversus, $Z$. dubius, $\boldsymbol{Z}$. bijugatus.

10-94-24-1, 118-119 cm; depth $488 \mathrm{~m}$ :

B. discula, C. dela, C. solitus, Ch. cristatus, C. staurion, $C$. bramlettei, $C$. formosa, $D$. barbadiensis, $D$. distinctus, $D$. gemmeus, $D$. mirus; $D$. sublodoensis, $D$. wemmelensis, $D$. plana, $H$. lophota, $H$. seminulum, $L$. mochlophorus, $L$. rotundus, $P$. larvalis, $R$. samodurovi, $R$. inflata, $R$. morionum, $R$. scabrosa, $S$. radians, T. inversus, $Z$. dubius, $Z$. bijugatus.

10-94-25-1, 63-64 cm; depth $497 \mathrm{~m}$ :

C. dela, C. grandis, C. solitus, C. eopelagicus, C. staurion, $C$. bramlettei, $C$. formosa, $D$. barbadiensis, $D$. distinctus, $D$. lodoensis, D. mirus, D. stradneri, D. sublodoensis, $D$. distincta, D. plana, D. solida, E. lajollaensis, $H$. lophota, $R$. samodurovi, $R$. inflata, $R$. scabrosa, S. fimbriata, $Z$. dubius, Z. bijugatus,

10-94-26-1, 125-126 cm; depth $501 \mathrm{~m}$ :

$B$. discula, C. dela, C. grandis, C. solitus, C. calathus, C. eopelagicus, $C$. pseudogammation, $C$. staurion, C. bramlettei, $C$. formosa, $D$. barbadiensis, $D$. lodoensis, $D$. sublodoensis, $D$. plana, $H$. lophota, $H$. seminulum, $R$. samodurovi [some specimens resemble $D$. scrippsae], $R$. inflata, $R$. tenuis, $S$. radians, $S$. fimbriata, $S$. formosa, $T$. inversus, $Z$. bijugatus.

10-94-26-2, 63-64 cm; depth $502 \mathrm{~m}$ :

$C$. dela, C. grandis, C. pseudogammation, C. formosa, $D$. barbadiensis, $B$. lodoensis, $D$. sublodoensis, $D$. versa [large] $H$. lophota, L. mochlophorus, $R$. samodurovi s.l., $R$. inflata, $S$. radians, $Z$. bijugatus. 
10-94-26-4, 63-64 cm; depth $505 \mathrm{~m}$ :

C. dela, C. grandis, C. solitus, C. calathus, C. pseudogammation, C. staurion, C. bramlettei, C. formosa, C. gammation, $D$. barbadiensis, $D$. lodoensis, $D$. mirus, $D$. sublodoensis, D. plana, E. lajollaensis, $H$. lophota, $H$. seminulum [small], L. mochlophorus, R. samodurovi s.l., $R$. morionum, $S$. radians, $T$. inversus, $Z$. dubius, $Z$. bijugatus.

Lower Eocene

(Discoaster lodoensis Zone)

10-94-28-1, 124-125 cm; depth $533 \mathrm{~m}$ :

C. dela, $C$. grandis, $C$. solitus, $C$. formosa, C. gammation, D. barbadiensis, D. lodoensis, D. mirus, D. distincta, D. versa [large], E. lajollaensis, $R$. samodurovi, s. l., S. radians, T. inversus, $Z$. dubius, $Z$. bijugatus.

10-94-28-2, 63-64 cm; depth $534 \mathrm{~m}$ :

$C$. dela, $C$. grandis, $C$. solitus, $C$. calathus, $C$. staurion, $C$. formosa [small], C. gammation, D. barbadiensis, Discoaster sp. cf. D. distinctus, D. lodoensis, D. mirus, D. sublodoensis, D. wemmelensis, D. plana, D. versa [large], $H$. lophota, $H$. seminulum, $R$. samodurovi s.l., $R$. morionum, $R$. truncata, $S$. radians, $Z$. dubius, $Z$. bijugatus.

10-94-28-4, 63-64 cm; depth $537 \mathrm{~m}$ :

C. dela, C. expansus, C. crassus, $C$. pseudogammation, $C$. formosa [small], C. gammation, D. barbadiensis, D. lodoensis, D. plana, D. versa [large], $H$. lophota, $H$. seminulum, $L$. rotundus, $R$. samodurovi s.l., $R$. spinula, $S$. radians, $S$. fimbriata, T. pulcher, T. inversus, $Z$. dubius, $Z$. bijugatus.

10-94-30-1, 62-63 cm; depth $571 \mathrm{~m}$ :

C. dela, C. conseutus, C. pelagicus s. l., D. barbadiensis, $D$. kuepperi, D. lodoensis, D. plana, E. lajollaensis, L. nascens, L. reniformis, Sphenolithus sp. aff. S. furacatolihoides, $S$. radians, Syracosphaera sp. cf. S. formosa, T. pulcheroides, $Z$. dubius, $Z$. bijugatus. Reworked Paleocene taxa: $C$. eodela, $S$. anarrhopus, $T$. craticulus.

10-94-30-2, 62-63 cm; depth $573 \mathrm{~m}$ : C. dela, C. eodela, C. pelagicus s.l., C. gammation, D. barbadiensis, $D$. lodoensis, D. kuepperi, D. plana, L. nascens, M. tribrachiatus, Sphenolithus sp. cf. S. anarrhopus, $S$. radians, $T$. pulcheroides, $Z$. bijugatus.

\section{Upper Paleocene \\ (Discoaster multiradiatus Zone, Campylosphaera eodela Subzone)}

10-94-33-1, 41-43 cm; depth $612 \mathrm{~m}$ :

$B$. discula, B. rosa, C. eodela, C. californicus, $C$. consuetus, C. pelagicus s. L., D. multiradiatus, D. ornatus, D. plana, T. eminens [small], $\boldsymbol{Z}$. distentus.

10-94-33-2, 43-45 cm; $614 \mathrm{~m}$ :

B. africana, C. eodela, C. consuetus, C. grandis, C. pelagicus s.l., D. multiradiatus, D. plana, S. anarrhopus, T. craticulus, $Z$. distentus.

10-94-34-3, 64-65 cm; depth $619 \mathrm{~m}$ :

C. eodela, C. californicus, C. consuetus, C. pelagicus s. L., D. lenticularis, $D$. multiradiatus, $D$. ornatus, $E$. macellus, $F$. tympaniformis, $T$. craticulus, $Z$. distentus.

\author{
Upper Paleocene \\ (Discoaster mohleri Zone)
}

10-94-35-1, 111-113 cm; depth $625 \mathrm{~m}$ :

C. californicus, C. consuetus, C. pelagicus s.l., C. ? robusta, $D$. mohleri, $D$. ornatus, $D$. rimosa, $E$. distichus, $F$. involutus, $F$. tympaniformis, $S$. anarrhopus, T. craticulus, $Z$. distentus.

\author{
Lower Paleocene \\ (Cruciplacolithus tenuis Zone)
}

10-94-36-1, 99-101 cm; depth $627 \mathrm{~m}$ :

B. bigelowi, C. pelagicus s.l., C. tenuis, Micrantholithus sp., Z. sigmoides.

Series Unknown

10-94-38-1, 63-64 cm; depth $635 \mathrm{~m}$ :

[Barren].

\author{
HOLE 95 \\ (lat $24^{\circ} 09.99^{\prime} \mathrm{N}$., long $86^{\circ} 23.85^{\prime} \mathrm{W}$., depth $1633 \mathrm{~m}$ ) \\ Pleistocene \\ (Gephyrocapsa oceanica Zone)
}

10-95-1-1, 63-64 cm; depth $1 \mathrm{~m}$ :

C. cristatus, D. perplexus, D. japonica, Discolithind? sp. cf. D.? macropora, D. multipora, G. caribbeanica, G. oceanica, $H$. kamptneri, $H$. sellii, $H$. wallichii, $O$. antillarum, $R$. clavigera, Scapholithus sp., S. apsteinii, S. histrica, Thoracosphaera sp. Reworked Miocene or Pliocene taxon: $C$. macintyrei.

10-95-1-5, 63-64 cm; depth $7 \mathrm{~m}$ :

$B$. bigelowi, C. cristatus, C. pelagicus [rare], D. perplexus, $D$. japonica, E. annula, $G$. oceanica, $H$. kamptneri, $H$. sellii, $R$. clavigera, $S$. histrica, Thoracosphaera sp., $U$. mirabilis. Reworked Miocene and Pliocene taxa: C. rugosus, C. macintyrei, D. deflandrei, D. pentaradiatus, D. surculus.

\section{Upper Oligocene \\ (Sphenolithus ciperoensis Zone)}

10-95-2-6, 63-64 cm; depth $90 \mathrm{~m}$ :

C. eopelagicus, $C$. fenestratus, C. neogammation, D. abisectus, D. scrippsae, D. deflandrei, $H$. intermedia, $H$. truncata, $R$. gartneri, S. ciperoensis, $S$. moriformis, T. carinatus [long].

\section{Middle Oligocene \\ (Sphenolithus distentus Zone)}

10-95-3-6, 63-64 cm; depth $129 \mathrm{~m}$ :

B. bigelowi, B. rosa, Chiasmolithus sp. [rims], C. eopelagicus, Coccolithus sp. cf. C. fenestratus, D. abisectus, D. bisectus, $D$. scrippsae, $D$. deflandrei, $D$. segmenta, $H$. intermedia, H. parallela, M. aequalis, $R$. gartneri, S. ciperoensis, $S$. distentus, $S$. moriformis, $S$. predistentus.

$$
\begin{gathered}
\text { Middle Oligocene } \\
\text { (Sphenolithus predistentus Zone) }
\end{gathered}
$$

10-95-4-4, 63-64 cm; depth $163 \mathrm{~m}$ :

$B$. bigelowi, $B$. rosa, $C$. eopelagicus, $C$. neogammation, $D$. bisectus, $D$. scrippsae, $D$. deflandrei, $D$. tani modifer, $H$. intermedia, $S$. predistentus, $Z$. bijugatus. 
10-95-5-1, 63-64 cm; depth $199 \mathrm{~m}$ :

$B$. bigelowi, B. discula, B. rosa, C. eopelagicus, C. fenestratus, $C$. neogammation, $D$. bisectus, D. scrippsae, $D$. deflandrei, D. tani tani, $H$. compacta [common], $H$. intermedia, L. minutus, $M$. aequalis, $P$. vadosa, $R$. gartneri, $S$. predistentus, $Z$. bijugatus.

10-95-5-4, 63-64 cm; depth $203 \mathrm{~m}$ :

B. bigelowi, B. rosa, C. eopelagicus, $C$. neogammation, $D$. bisectus, $D$. scrippsae, D. deflandrei, D. tani tani, H. compacta, $P$. joidesa, $P$. vadosa, $R$. gartneri, $S$. moriformis, $S$. predistentus, $Z$. bijugatus.

\section{Upper Eocene \\ (Discoaster barbadiensis Zone)}

10-95-6-1, 63-64 cm; depth $237 \mathrm{~m}$ :

B. bigelowi, B. rosa, B. serraculoides, C. eopelagicus, C. formosa, C. protoannula, C. reticulata, D. bisectus, $D$. scrippsae, D. barbadiensis, D. saipanensis, D. tani nodifer, D. tani tani, $H$. compacta, M. aequalis, P. joidesa, P. vadosa, $R$. umbilica, S. moriformis, Z. bijugatus.

10-95-6-6, 63-64 cm; depth $244 \mathrm{~m}$ :

B. bigelowi, B. serraculoides, $C$. eopelagicus, $C$. formosa, $C$. neogammation, $C$. protoannula, D. bisectus, D. scrippsae, $D$. barbadiensis, $D$. saipanensis, $D$. tani nodifer, $D$. tani tani, $H$. compacta, $L$. minutus, $M$. aequalis, $M$. basquensis, $M$. inaequalis, $P$. papillatum, $P$. joidesa, S. pseudoradians, $Z$. bijugatus.

\section{Middle Eocene \\ (Chiphragmolithus quadratus Zone)}

10-95-7-1, 63-64 cm; depth $275 \mathrm{~m}$ :

B. bigelowi, B. discula [abundant], B. rosa, B. seraculoides, $C$. dela, C. consuetus, C. grandis, C. solitus, C. fulgens, $C$. spinosus, C. eopelagicus, C. fenestratus, C. staurion, D. barbadiensis, $D$. deflandrei, $D$. tani nodifer, Helicopontosphaera sp. cf. $H$. compacta, $M$. inversus, $R$. samodurovi, $S$. furcatolithoides, $S$. pseudoradians, T. inversus, $Z$. bijugatus.

10-95-7-6, 62-63 cm; depth $282 \mathrm{~m}$ :

$B$. discula, B. rosa, B. serraculoides [few, small], $C$. dela, C. grandis, C. solitus, C. spinosus, $C$. epogelagicus, $C$. pseudogammation, C. staurion, $C$. formosa, D. barbadiensis, D. gemmeus, D. plana, Helicopontosphaera sp. cf. $H$. lophota, $R$. samodurovi, $S$. furcatolithoides, $T$. inversus.

\section{Middle Eocene \\ (Discoaster sublodoensis Zone)}

10-95-8-1, 63-64 cm; depth $333 \mathrm{~m}$ :

C. dela, C. grandis, C. eopelagicus, C. pseudogammation, C. staurion, C. formosa, C. bramlettei, D. barbadiensis, $D$. mirus, D. sublodoensis, $H$. lophota $R$. inflata [common], $S$. radians, Triquetrorhabdulus sp. cf. T. inversus, $Z$. bijucatus.

10-95-8-6, 62-63 cm; depth $340 \mathrm{~m}$ :

C. dela, C. grandis, C. acanthodes, C. pseudogammation, C. staurion, C. formosa, C. bramlettei, D. barbadiensis, Discoaster sp. cf. D. distinctus, D. gemmeus, Discoaster sp. cf. D. stradneri, D. sublodoensis, H. lophota, Triquetrorhabdulus sp. cf. $T$. inversus, $Z$. bijugatus.

\section{Upper Paleocene \\ (Discoaster multiradiatus Zone, Campylosphaera eodela Subzone)}

10-95-10-1, 61-62 cm; depth $364 \mathrm{~m}$ :

$B$. bigelowi, $B$. discula, $C$. eodela, $C$. consuetus, $D$. delicatus, $D$. lenticularis, $D$. multiradiatus, $D$. ornatus, $D$. rimosa, E. macellus, $F$. tympaniformis, $S$. anarrhopus, $T$. craticulus, $Z$. adamas, $Z$. distentus, $Z$. simplex.

Lower Paleocene

(Cruciplacolithus tenuis Zone)

10-95-11-1, 108-110 cm; depth $377 \mathrm{~m}$ :

$B$. africana, B. bigelowi, $B$. discula, $B$. rosa, C. pelagicus s.l., $C$. tenuis, Thoracosphaera sp., $Z$. sigmoides.

10-95-12-1, 60-62 cm; depth $386 \mathrm{~m}$ :

B. bigelowi, B. discula, C. pelagicus s.l., C. tenuis, Z. sigmoides.

Cretaceous or Lower Paleocene

10-95-13-1, 63-64 cm; depth $395 \mathrm{~m}$ :

B. bigelowi, B. discula, W. Barnesae [rare], Z. sigmoides [rare].

\section{Upper Cretaceous \\ (Lower Campanian or Upper Santonian)}

10-95-13-4, 63-64 cm; depth $400 \mathrm{~m}$ :

Amphizygus sp., A. gronosa, B. turbinea, B. parca, C. amphipons, $C$. conicus, $C$. serratus, $E$. augustus, $M$. decussata, $W$. barnesae, $Z$. deflandrei, $Z$. minimus, $Z$. phacelosus.

10-95-14-1, 74-75 cm; depth $400 \mathrm{~m}$ :

Amphizygus sp., A. gronosa, B. turbinea, B. parca, C. amphipons, $C$. signum, E. augustus, $G$. concavum, L. grilli, $M$. decussata, $P$. multicarinata, $W$. barnesae, $Z$. deflandrei, $Z$. phacelosus.

10-95-15-4, 64-65 cm; depth $413 \mathrm{~m}$ :

$A$. gronosa, B. turbinea, C. amphipons, C. signum, E. augustus, $E$. turriseiffeli, W. barnesae, $Z$. deflandrei.

\section{Upper Cretaceous (Santonian)}

10-95-16-3, 63-64 cm; depth $421 \mathrm{~m}$ :

$A$. gronosa, C. amphipons, C. bifarius, E. augustus, $E$. turriseiffeli, Micrantholithus sp., W. barnesae, $Z$. deflandrei.

10-95-17-1, 63-64 cm; depth $427 \mathrm{~m}$ :

A. gronosa, C. amphipons, C. signum, E. augustus, E. turriseiffeli, Marthasterites sp. cf. M. furcatus furcatus, Micrantholithus sp., $M$. decussata, $P$. augustus, $W$. barnesae, $Z$. deflandrei, $Z$. minimus.

10-95-17-3, 63-64 cm; depth $430 \mathrm{~m}$ :

$A$. gronosa, B. rotatorius, $C$. amphipons, $C$. interruptus, $E$. turriseiffeli, Marthasterites sp. cf. M. furcatus, M. decussata, $P$. angustus, $W$. barnesae, $Z$. deflandrei, $Z$.? variradiatus. 
10-95-17-6, 62-63 cm; depth $434 \mathrm{~m}$ :

A. gronosa, B. rotatorius, C. amphipons, C. signum, E. augustus, E. turriseiffeli, L. cayeuxi, L. maleformis, Marthasterites sp. cf. M. furcatus furcatus, S. laffittei, W. barnesae, $Z$. deflandrei.

\section{HOLE 96}

(lat $23^{\circ} 44.56^{\prime} \mathrm{N}$., long $85^{\circ} 45.80^{\prime} \mathrm{W}$., depth $3439 \mathrm{~m}$ )

Pleistocene (?) With Reworked Upper Cretaceous

10-96-1-2, 63-64 cm; depth $102 \mathrm{~m}$ :

H. kamptneri. Reworked Upper Cretaceous taxa: C. ehrenbergii, E. augustus, $M$. decussata, $P$. cretacea, $W$. barnesae.

10-96-1-4, 63-64 cm; depth $105 \mathrm{~m}$ :

Reworked Upper Cretaceous taxa: A. gronosa, B. parca, $C$. amphipons, C. disgregatus, $C$. ehrenbergii, $E$. augustus, $G$. concavum, G. costatum costatum, M. simplex, M. decussata, $P$. cretacea, T. gothicus trifidus, $V$. octoradiata, $W$. barnesae, $Z$. compactus, $Z$. deflandrei, $Z$. lacunatus, $Z$. phacelosus.

10-96-1-6, 63-64 cm; depth $108 \mathrm{~m}$ :

Reworked Upper Cretaceous taxa: A. snyderi, A. cymbiformis, B. parca, C. amphipons, C. disgregatus, C. ehrenbergii, E. augustus, E. turriseiffeli, G. costatum costatum, $M$. furcatus, $M$. decussata, $M$. decoratus, $P$. cretacea, $V$. octoradiata, $W$. barnesae, $W$. biporta, $Z$. deflandrei, $Z$. lacunatus.

\section{Upper Oligocene \\ (Sphenolithus ciperoensis Zone)}

10-96-2-1, 63-64 cm; depth $200 \mathrm{~m}$ :

C. eopelagicus, C. fenestratus, C. neogammation, D. abisectus, D. scrippsae, D. deflandrei, D. segmenta, $H$. intermedia, $H$. parallela, $H$. truncata, $H$. wilcoxoniil, $S$. moriformis, $T$. carinatus, $\boldsymbol{Z}$. bijugatus.

10-96-2-3, 63-64 cm; depth $203 \mathrm{~m}$ :

C. eopelagicus, $C$. neogammation, D. abisectus, D. bisectus, $D$. scrippsae, $D$. deflandrei, D. segmenta, $H$. intermedia, $H$. parallela, $S$. ciperoensis, $S$. moriformis.

10-96-2-6,63-64 cm; depth $207 \mathrm{~m}$ :

C. eopelagicus, $C$. fenestratus, D. abisectus, D. bisectus, $D$. scrippsae, $D$. deflandrei, $D$. tani nodifer, D. segmenta, $H$. parallela, H. truncata, $R$. gartneri, S. distentus, S. moriformis, T. carinatus, $Z$. bijugatus.

\section{Upper Paleocene \\ (Discoaster multiradiatus Zone, \\ Campylosphaera eodela Subzone)}

10-96-3-1, 63-64 cm; depth $302 \mathrm{~m}$ :

$C$. eodela, $C$. bidens, $D$. lenticularis, $D$. multiradiatus, $D$. ornatus, $D$. rimosa, $R$. cuspis, $T$. eminens, $Z$. distentus.

10-96-3-6, 63-64 cm; depth $309 \mathrm{~m}$ :

B. bigelowi, C. eodela, C. bidens, C. consuetus, Discoaster sp. cf. D. araneus, Discoaster sp. cf. D. mediosus, D. multiradiatus, $D$. ornatus, $D$. rimosa, $R$. cuspis, $T$. eminens, $Z$. distentus.
10-96-5-1, 61-62 cm; depth $330 \mathrm{~m}$ :

$B$. bigelowi, C. eodela, C. bidens, C. californicus, C. consuetus, $D$. lubinaensis, $D$. multiradiatus, $D$. ornatus, $D$. rimosa, $E$. distichus, $F$. tympaniformis, $T$. eminens, $Z$. distentus. Miocene taxon present as contaminant: $D$. berggrenii.

\section{HOLE 97}

(lat $23^{\circ} 53.05^{\prime} \mathrm{N}$., long $84^{\circ} 26.74^{\prime}$ W., depth $2930 \mathrm{~m}$ )

\section{Holocene \\ (Emiliania huxleyi Zone)}

10-97-1-1, 92-93 cm; depth $1 \mathrm{~m}$ :

C. cristatus [large], Discolithina sp. cf. D. japonica, ?E. huxleyi, G. oceanica, H. kamptneri, H. sellii, P. scutellum, $R$. stylifera, Scapholithus sp., S. histrica, Thoracosphaera sp., U. mirabilis. Reworked Miocene or Pliocene taxa: $C$. macintyrei, $D$. brouweri, $D$. deflandrei.

\section{Upper Pleistocene \\ (Gephyrocapsa oceanica Zone)}

10-97-1-2, 63-64 cm; depth $2 \mathrm{~m}$ :

C. cristatus, C. leptopora, G. oceanica, Gephyrocapsa sp. [small], H. kamptneri, P. scutellum, R. clavigera, Scapholithus sp., S. histrica, Thoracosphaera spp. Reworked Upper Cretaceous taxa: $B$. parca, $M$. decussata.

\section{Lower Pleistocene \\ (Coccolithus doronicoides Zone)}

10-97-1-4, 63-64 cm; depth $5 \mathrm{~m}$ :

C. doronicoides, C. pelagicus, C. leptopora, C. macintyrei [rare], D. brouweri [few], D. perplexus, D. japonica, $E$. annula, $H$. kamptneri, $H$. sellii, $R$. clavigera, Scapholithus sp., S. apsteinii, S. pulcherrima, S. histrica, U. mirabilis.

\section{Upper Miocene \\ (Discoaster quinqueramus Zone)}

10-97-2-1, 63-64 cm; depth $106 \mathrm{~m}$ :

C. pelagius, C. leptopora, C. macintyrei, $D$. brouweri s.l., $D$. pentaradiatus, $D$. quinqueramus, $D$. surculus $D$. variabilis variabilis, $H$. kamptneri, $S$. abies, T. rugosus.

10-97-2-4, 63-64 cm; depth $110 \mathrm{~m}$ :

$C$. pelagicus [abundant], C. macintyrei, $D$. berggrenii, $D$. brouweri s.l., $D$. challengeri, $D$. perclarus, $D$. quinqueramus, D. surculus, D. variabilis variabilis, $H$. kamptneri, $H$. sellii, $S$. abies, $S$. neoabies, $T$. rugosus.

\section{Upper Miocene, With Mixing \\ (Discoaster neohamatus Zone)}

10-97-3-3, 63-64 cm; depth $144 \mathrm{~m}$ :

C. pelagicus, C. macintyrei, C. rotula, $D$. braarudii, $D$. brouweri s.l., D. challengeri, Discoaster sp. cf. D. hamatus, $D$. neohamatus, D. perclarus, Discoaster sp. cf. D. pentaradiatus, $D$. variabilis variabilis, $H$. kamptneri $H$. sellii $R$. pseudoumbilica, $S$. neoabies, $T$. rugosus. Reworked Miocene taxa: $C$. coalitus, $C$. neogammation, $D$. bollii, $D$. calcaris, $D$. deflandrei, $D$. hamatus.

\section{Upper Miocene, With Mixing \\ (Discoaster hamatus Zone)}

10-97-4-2, 10-11 cm; depth $202 \mathrm{~m}$ :

C. calyculus, $C$. pelagicus, C. macintyrei, C. rotula, D. braarudii, D. calcaris, D. hamatus, D. bellus, D. subsur- 
culus, D. variabilis variabilis, $H$. kamptneri, $H$. sellii, $R$. pseudoumbilica [abundant], S. abies, T. rugosus. Reworked Miocene taxa: $C$. eopelagicus, $D$. deflandrei, $D$. kugleri, D. moorei, D. signus.

\section{Middle Oligocene \\ (Sphenolithus distentus Zone)}

10-97-4-2, 63-64 cm; depth $202 \mathrm{~m}$ :

C. altus, $C$. eopelagicus, C. neogammation, D. abisectus, $D$. deflandrei, $H$. intermedia, $H$. parallela, $H$. truncata, $S$. distentus, $S$. moriformis, $S$. predistentus, $Z$. bijugatus.

10-97-4-5, 63-64 cm; depth $207 \mathrm{~m}: B$. bigelowi, C. eopelagicus, C. neogammation. D. abisectus, D. scrippsae, D. deflandrei, H. truncata, P. joidesa, R. gartneri, Scyphosphaera sp., S. distensus, S. moriformis, Thoracosphaera sp., Z. bijugatus.

\section{Upper Eocene \\ (Discoaster barbadiensis Zone)}

10-97-5-1, 127-128 cm; depth $250 \mathrm{~m}$ :

$B$. serraculoides, C. eopelagicus, C. formosa, C. protoannula, $D$. bisectus, $D$. scrippsae, $D$. deflandrei, $D$. saipanensis, $D$. tani nodifer, $D$. tani tani, $P$. vadosa, $R$. umbilica, $Z$. bijugatus.

\section{Upper Cretaceous}

10-97-6-1, 117-118 cm; depth $295 \mathrm{~m}$ :

A. gronosa, C. amphipons, E. turriseiffeli, Parhabdolithus sp. cf. $P$. embergeri, $W$. barnesae.

10-97-7-1, 109-110 cm; $305 \mathrm{~m}$ :

A. gronosa, C. amphipons, C. signum, C. crenulatus, E. turriseiffeli, P. angustus, Prediscosphaera sp., W. barnesae, Zygodiscus spp.

10-97-7-2, 60-61 cm; $306 \mathrm{~m}$ :

[Barren].

10-97-8-1, 75-76 cm; depth $308 \mathrm{~m}$ :

W. barnesae [rare].

10-97-8-4, 63-64 cm; depth $313 \mathrm{~m}$ :

Bidiscus sp., C. amphipons, C. crenulatus, C. ehrenbergii, E. turriseiffeli, Parhabdolithus sp. cf. P. embergeri, $W$. barnesae.

\section{Upper Cretaceous \\ (Lower Cenomanian)}

10-97-12-1, 31-32 cm; depth $333 \mathrm{~m}$ :

A. gronosa, Biscutum sp., Chiastozygus sp. cf. C. amphipons, C. matalosus, C. crenulatus, C. decorus, E. tur- riseiffeli, $P$. augustus, $P$. embergeri, $P$. granulatus, Prediscosphaera sp., W. barnesae, Watznaueria sp. aff. W. britannica, Z. gabalus, Z. ponticulus.

\section{REFERENCES}

Boudreaux, J.E. and Hay, W.W., 1969. Calcareous nannoplankton and biostratigraphy of the late Pliocene-PleistoceneRecent sediments in the Submarex cores. Revista Espanola de Micropaleontologia. 1, 249.

Bramlette, M.N. and Wilcoxon, J.A., 1967. Middle Tertiary calcareous nannoplankton of the Cipero section, Trinidad, W.I. Tulane Stud. Geol. 5, 93.

Bukry, D., 1970. Coccolith age determinations Leg 2, Deep Sea Drilling Project. Initial Reports of the Deep Sea Drilling Project, Volume II. Washington (U.S. Government Printing Office). 349.

1971a. Coccolith stratigraphy Leg 7, Deep Sea Drilling Project. Initial Reports of the Deep Sea Drilling Project, Volume VII. Washington (U.S. Government Printing Office). 1513 .

1971b. Coccolith stratigraphy Leg 9, Deep Sea Drilling Project. Initial Reports of the Deep Sea Drilling Project, Volume IX. Washington (U.S. Government Printing Office). 817.

Bukry, D. and Bramlette, M.N., 1970. Coccolith age determinations Leg 3, Deep Sea Drilling Project. Initial Reports of the Deep Sea Drilling Project, Volume III. Washington (U.S. Government Printing Office). 589.

Bukry, D., Douglas, R.G., Kling, S.A. and Krasheninnikov, V., 1971. Planktonic microfossil biostratigraphy of the northwestern Pacific Ocean. Initial Reports of the Deep Sea Drilling Project, Volume VI. Washington (U.S. Government Printing Office). 1253.

Gartner, S., Jr. and Bukry, D., 1969. Tertiary holococcoliths. J. Paleontology. 43, 1213.

Gran, H.H. and Braarud, T., 1935. A quantitative study of the phytoplankton in the Bay of Fundy and the Gulf of Maine (including observations on hydrography, chemistry and turbidity). J. Biol. Board Canada. 1, 279.

Hsü, K.J. and Andrews, J.E., 1970, Lithology. Initial Reports of the Deep Sea Drilling Project, Volume III. Washington (U.S. Government Printing Office). 445.

McIntyre, A. and Bé, A.W.H., 1967. Modern Coccolithophoridae of the Atlantic Ocean-I. Placoliths and Cyrtoliths. Deep-Sea Res. 14, 561.

Smayada, T.J., 1966. A quantitative analysis of the phytoplankton of the Gulf of Panama. III General ecological conditions and the phytoplankton dynamics at $8^{\circ} 45^{\prime} \mathrm{N}, 79^{\circ} 23^{\prime} \mathrm{W}$ from November 1954 to May 1957. Bull. Inter-Amer. Trop. Tuna Comm. 11, 355. 